\title{
Active tectonics of the Eastern Mediterranean region: deduced from GPS, neotectonic and seismicity data
}

\author{
Aykut Barka $\left({ }^{1}\right)$ and Robert Reilinger $\left({ }^{2}\right)$ \\ ( $\left.{ }^{1}\right)$ ITÜ, Maden Fakültesi, Jeoloji Bölümü, Ayază̆a, İstanbul, Turkey \\ ${ }^{2}$ ) Massachussetts Institute of Technology, Cambridge, MA, U.S.A.
}

\begin{abstract}
This paper reviews the main tectonic features of the Eastern Mediterranean region combining the recent information obtained from GPS measurements, seismicity and neotectonic studies. GPS measurements reveal that the Arabian plate moves northward with respect to Eurasia at a rate of $23 \pm 1 \mathrm{~mm} / \mathrm{yr}, 10 \mathrm{~mm} / \mathrm{yr}$ of this rate is taken up by shortening in the Caucasus. The internal deformation in Eastern Anatolia by conjugate strike-slip faulting and $\mathrm{E}-\mathrm{W}$ trending thrusts, including the Bitlis frontal thrust, accommodates approximately a $15 \mathrm{~mm} / \mathrm{yr}$ slip rate. The Northeast Anatolian fault, which extends from the Erzincan basin to Caucasus accommodates about $8 \pm 5 \mathrm{~mm} / \mathrm{yr}$ of left-lateral motion. The neotectonic fault pattern in Eastern Anatolia suggests that the NE Anatolian block moves in an E-ENE direction towards the South Caspian Sea. According to the same data, the Anatolian-Aegean block is undergoing a counter-clockwise rotation. However, from the residuals it appears that this solution can only be taken as a preliminary approximation. The Eulerian rotation pole indicates that slip rate along the North Anatolian fault is about $26 \pm 3 \mathrm{~mm} / \mathrm{yr}$. This value is $10 \mathrm{~mm} / \mathrm{yr}$ higher than slip rates obtained from geological data and historical earthquake records and it includes westward drift of the Pontides of a few millimetres/year or more. GPS measurements reveal that the East Anatolian fault accommodates an $11 \pm 1 \mathrm{~mm} / \mathrm{yr}$ relative motion. GPS data suggest that Central Anatolia behaves as a rigid block, but from neotectonic studies, it clearly appears that it is sliced by a number of conjugate strike-slip faults. The Isparta Angle area might be considered a major obstacle for the westward motion of the Anatolian block (Central and Eastern Anatolia). The western flank of this geological structure, the Fethiye-Burdur fault zone appears to be a major boundary with a slip rate of $15-20 \mathrm{~mm} / \mathrm{yr}$. The Western Anatolian grabens take up a total of $15 \mathrm{~mm} / \mathrm{yr}$ NE-SW extension. The fact that motions in Central Anatolia relative to Eurasia, are $15-20 \mathrm{~mm} / \mathrm{yr}$ while in Western Anatolia and Aegean Sea they are $30-40 \mathrm{~mm} / \mathrm{yr}$ could suggest that Western Anatolia decouples from Central Anatolia and the Isparta Angle by the Fethiye-Burdur fault zone and Eskişehir fault. It is also hypothesized that the differentiation of tectonic styles and velocities in the Anatolian-Aegean block are related to differences between the slabs lying under the Cyprus and Hellenic arcs.
\end{abstract}

Key words Global Positioning System (GPS) neotectonics - seismicity

\section{Introduction}

Recent tectonics of the Eastern Mediterranean region is very complex and has been studied intensely for the last 30 years since ini-

Mailing address: Prof. Aykut Barka, ITÜ, Maden Fakültesi, Jeoloji Bölümü, Ayazağa, İstanbul, Turkey; e-mail: barka@sariyer.cc.itu.edu.tr tiation of the plate-tectonic concept. The Eastern Mediterranean region, which defines the region lying between the Caspian Sea and the Adriatic Sea through Caucasus, Anatolia, Aegean Sea and Greece, is the one of the world's most seismically active regions (figs. 1-3). Deadly earthquakes occurring in this region during the last 20 years are: 1975 Lice $\left(M_{s}=6.6\right.$, Turkey, Arpat, 1977a; Eyidoğan, 1980); 1976 Çaldıran $\left(M_{s}=7.1\right.$, Turkey, Arpat, $1977 b) ; 1983$ Horasan-Narman $\left(M_{s}=6.8\right.$, Turkey, Barka et al., 1983); 1988 Spitak, 


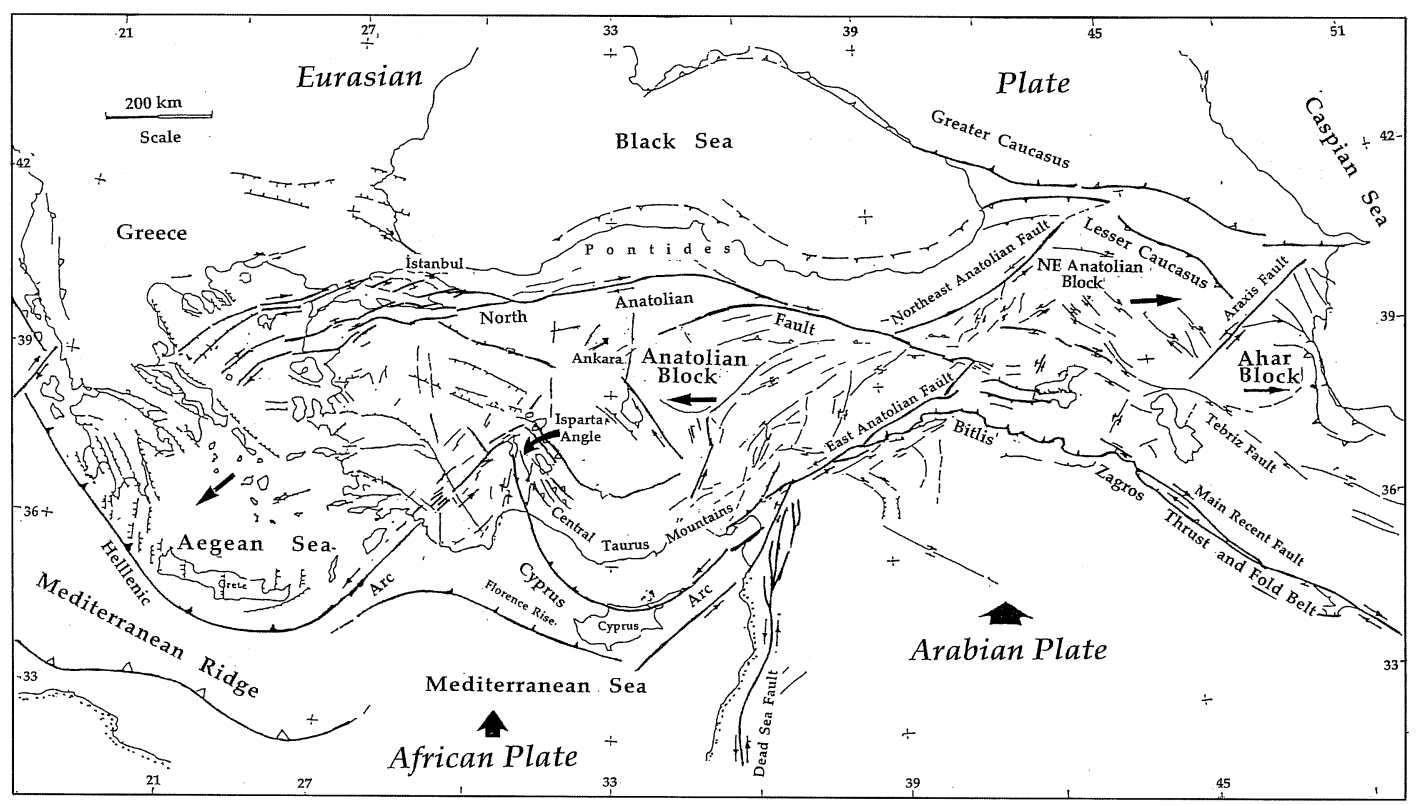

Fig. 1. Distribution of active faults in the Anatolian region. Modified from Şengör et al. (1985), Şaroğlu et al. (1987), Barka (1992) and Armijo et al. (1992).

Armenia $\left(M_{s}=6.7\right.$, Haessler et al., 1992); 1990 Iran $\left(M_{s}=7.7\right.$, Fuenzalida, 1995); 1991 Rach $\left(M_{s}=7.0\right.$, Georgia, Fuenzalida et al., 1997a); 1992 Erzincan $(M=6.8$, Turkey, Barka and Eyidoğan, 1993; Fuenzalida et al., 1997b); 1995 Western Macedonia $\left(M_{s}=6.6\right.$, Greece, Stiros, 1995); 1995 Dinar $\left(M_{s}=6.1\right.$, Turkey, Eyidoğan and Barka, 1996), (fig. 3).

Global kinematic models (NUVEL-1A; DeMets et al., 1990, 1994) based on the analysis of oceanic spreadings, fault systems, and earthquake slip vectors indicate that the Arabian plate is moving in a north-northwest direction relative to Eurasia at a rate of about $25 \mathrm{~mm} / \mathrm{yr}$, averaged over about $3 \mathrm{Ma}$. This motion, resulting in a continental collision along the Bitlis-Zagros fold and thrust belt, is thought to cause intense seismic activity (fig. 2). The African plate is moving in a northerly direction relative to Eurasia, at a rate of about $10 \mathrm{~mm} / \mathrm{yr}$. The differential motion between Africa and Arabia $(\sim 15 \mathrm{~mm} / \mathrm{yr})$ is thought to be taken up predominantly by leftlateral motion along the Dead Sea transform fault (fig. 1), (e.g., Freund et al., 1970). GPS velocities for the two sites located south of the Bitlis suture both indicate NW oriented motion relative to Eurasia ( $18 \pm 5 \mathrm{~mm} / \mathrm{yr}$ ), (Reilinger et al., 1995, 1997) somewhat slower, but not statistically different from NUVEL-1A estimates (24 $\pm 6 \mathrm{~mm} / \mathrm{yr}$ ), (fig. 4).

The analysis of 1988-1994 GPS measurements in Turkey indicates that the Anatolian block is undergoing counter-clockwise rotation about a pole located north of Sinai $\left(33.4^{\circ} \mathrm{E}\right.$, $31.1^{\circ} \mathrm{N}$ ), (fig. 4, Reilinger et al. 1995). The Anatolian block escapes from Eastern Anatolia due to Eurasia and Arabian collision and moves onto the African oceanic plate along the Hellenic arc. In this paper, we will review the main tectonic elements of the Eastern Mediterranean region by combining recent information obtained from GPS measurements, seismicity and neotectonic observations. 
42

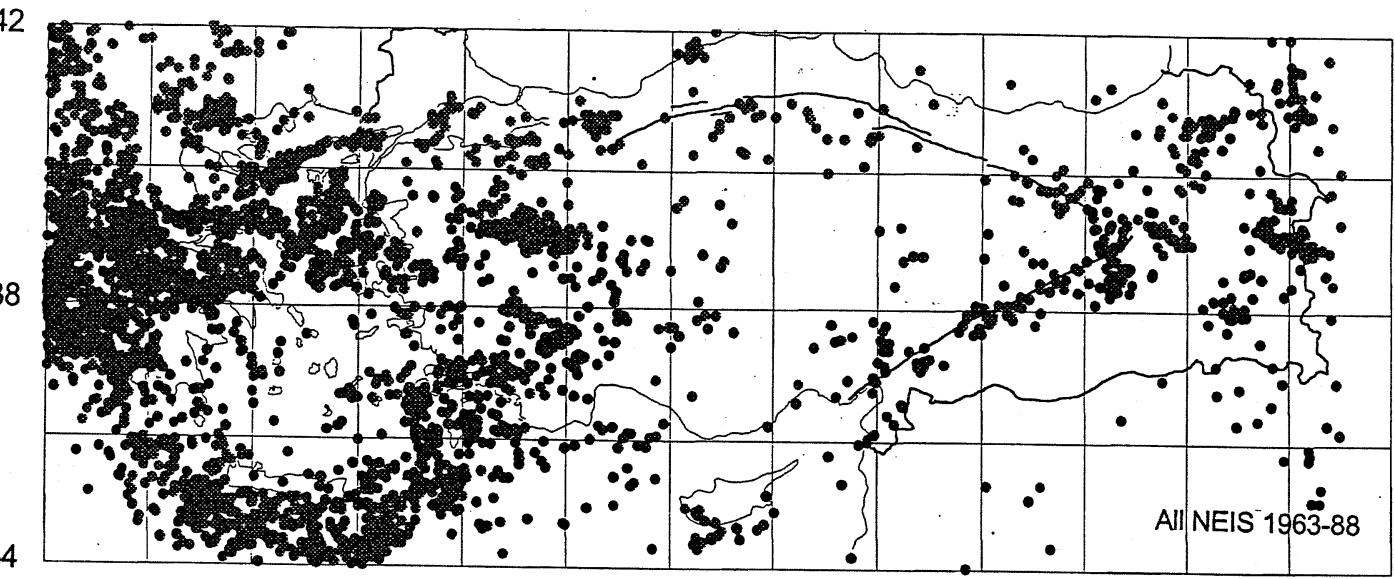

Fig. 2. Seismic activity of the Anatolian region between 1963-1988. Modified from Jackson (1994).

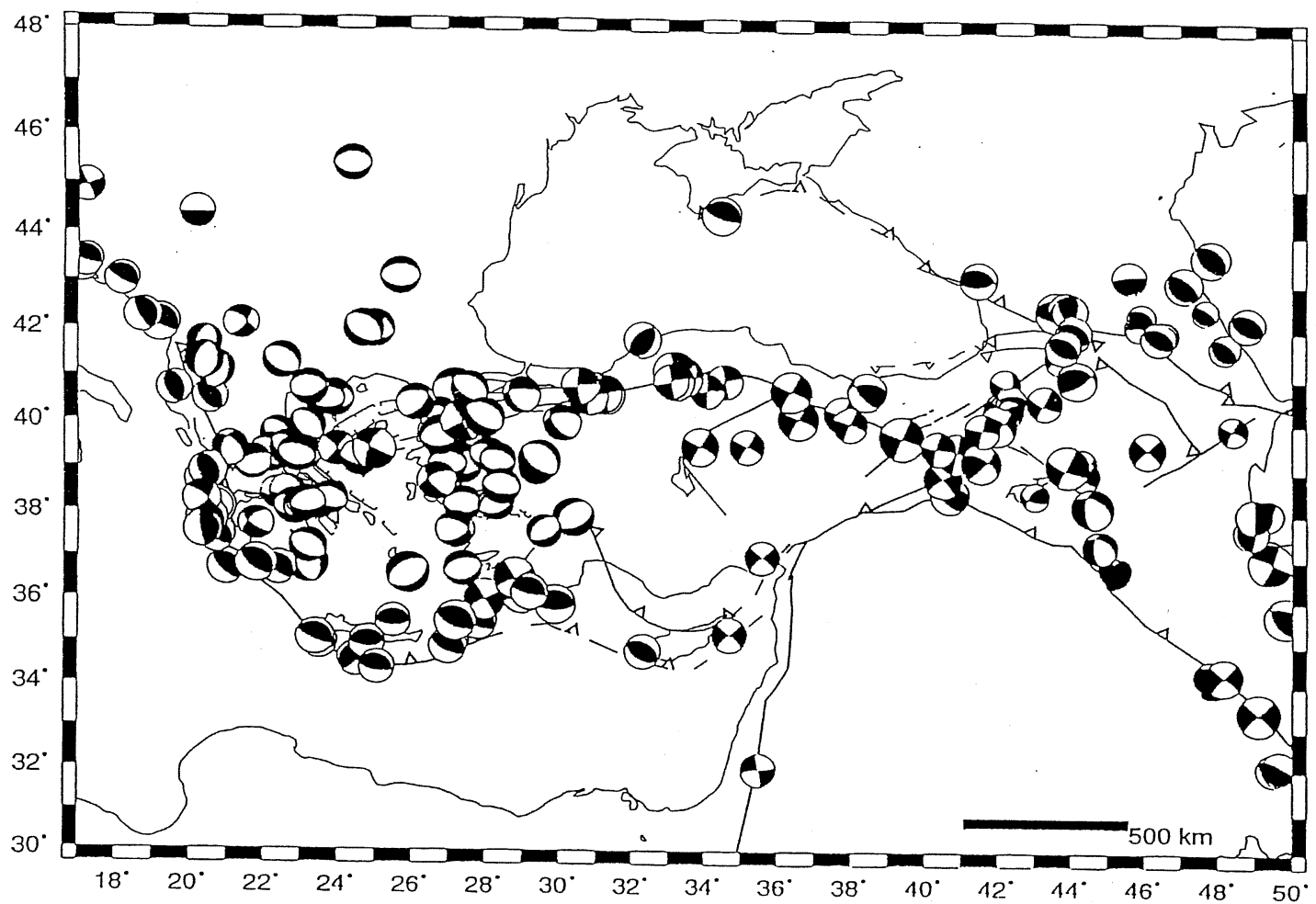

Fig. 3. Distribution of fault plane solutions in the Eastern Mediterranean region, documented from McKenzie (1972, 1978), Jackson and McKenzie (1984). From Reilinger et al. (1997). 


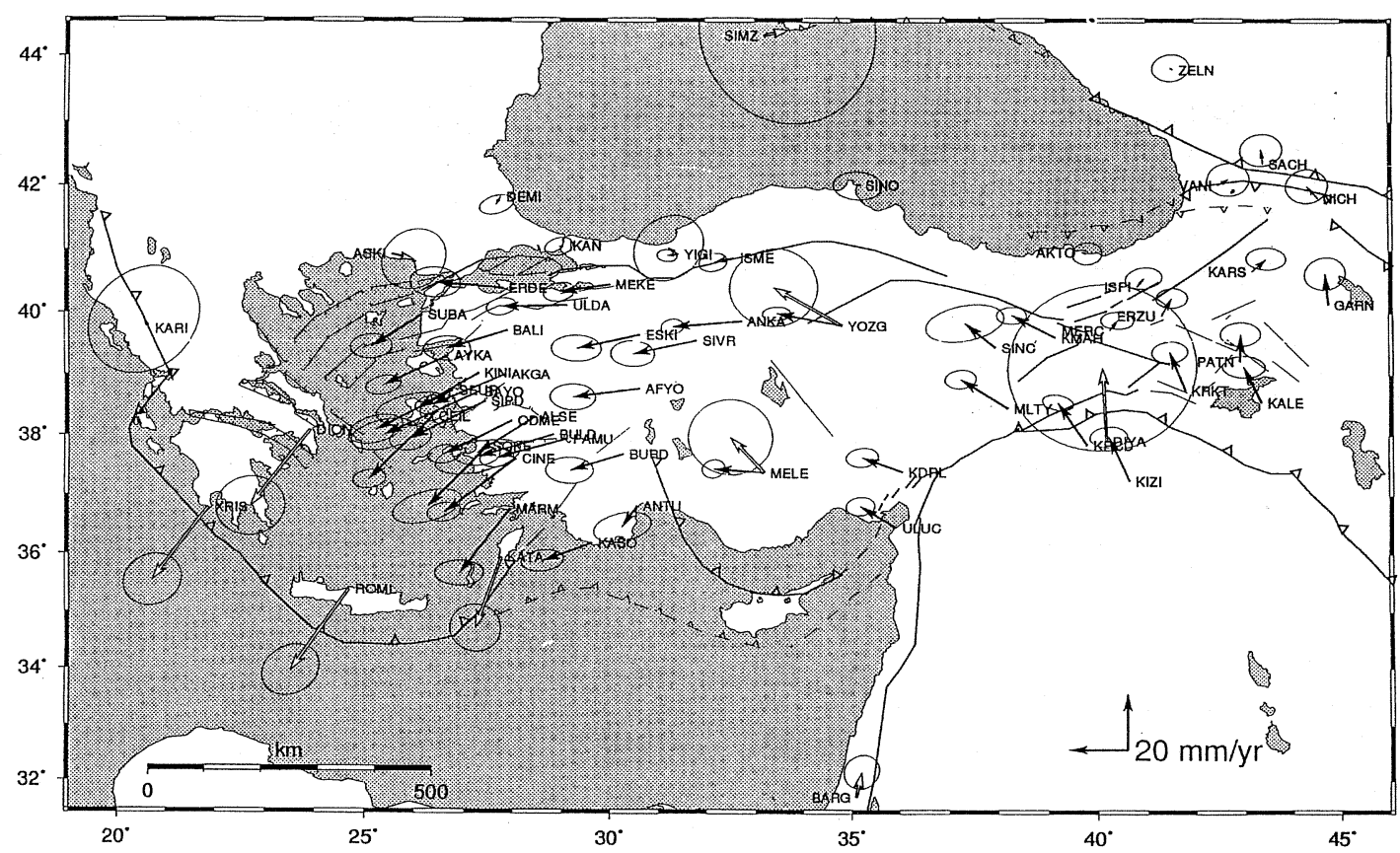

Fig. 4. Distribution of GPS velocity vectors measured between 1988-1994 in the Eastern Mediterranean region (Reilinger et al., 1997). Open arrows are SLR measurements taken from Robbins et al. (1995).

\section{Eastern Anatolia and Caucasus}

Neotectonics in Eastern Anatolia (figs. 5 and 6) involves four types of structures: NESW trending sinistral faults (Horasan-Narman fault, Erzurum fault zone, Malazgirt faults), NW-SE trending dextral faults (ÇaldıranTutak-Karayazı fault, Balıkgölü fault), E-W trending thrusts (Muş-Van thrust) and N-S trending extension cracks and/or normal faults (giving rise to volcanic activity, Nemrut and Süphan volcanoes), (fig. 6), (Şaroğlu and Güner, 1981; Şengör et al., 1985; Dewey et al., 1986; Barka and Kadinsky-Cade, 1988).

The 1975 Lice earthquake, $M=6.6$, occurred in the western part of the Bitlis frontal thrust (Eyidoğan, 1980). The 1976 Çaldıran earthquake had a right-lateral mechanism and created a $50 \mathrm{~km}$ long surface rupture (Arpat, 1977b), (fig. 7). The 1983 Horasan-Narman earthquake, $M=6.8$ took place on the NE-SW trending left-lateral Horasan-Narman fault east of Erzurum (Barka et al., 1983).

Figure 8 shows aftershock distribution and fault plane solution of the main shock of the 1983 earthquake (Eyidoğan, 1990). The 1988 Spitak earthquake occurred south of the Pambak-Sevan fault and exhibited dominant thrust solution even though the Pambak-Sevan fault is dominantly right-lateral strike-slip (Haessler et al., 1992). It is suggested that this earthquake was related to a positive flower structure along the Pambak-Sevan fault due to the compressional bend along the fault. From GPS measurements (fig. 4), we estimate a $7 \pm 2 \mathrm{~mm} / \mathrm{yr}$ right-lateral slip on the ÇaldıranTutak-Karayazı fault system and about $15 \mathrm{~mm} / \mathrm{yr} \mathrm{N}-\mathrm{S}$ shortening is taken up by Eastern Anatolia including Bitlis thrust (Reilinger et al., 1995).

Fault slip rates for the range-bounding faults of the Lesser and Greater Caucasus are diffi- 
cult to estimate given the wide station spacing. Overall shortening roughly $\mathrm{N}-\mathrm{S}$ is estimated in $10 \pm 2 \mathrm{~mm} / \mathrm{yr}$, (Reilinger et al., 1997). There is weak evidence that this shortening is distributed more or less equally between the lesser and Greater Caucasus. The recent 1991 Rach, Georgia, earthquake $M_{s}=7.0$, had a thrust solution, consistent with the type of deformation observed in the Caucasus (Fuenzalida et al., 1997a).

\section{The Northeast Anatolian fault zone}

The Northeast Anatolian fault zone extends from near the city of Erzurum, Turkey northeast to the Caucasus mountains (figs. 1 and 5; Barka and Kadinsky-Cade, 1988). This fault zone may include the Borjomi-Kazbeg fault which crosses the Caucasus mountains as defined by Philip et al. (1989). The Northeast Anatolian fault zone consists of several seg-

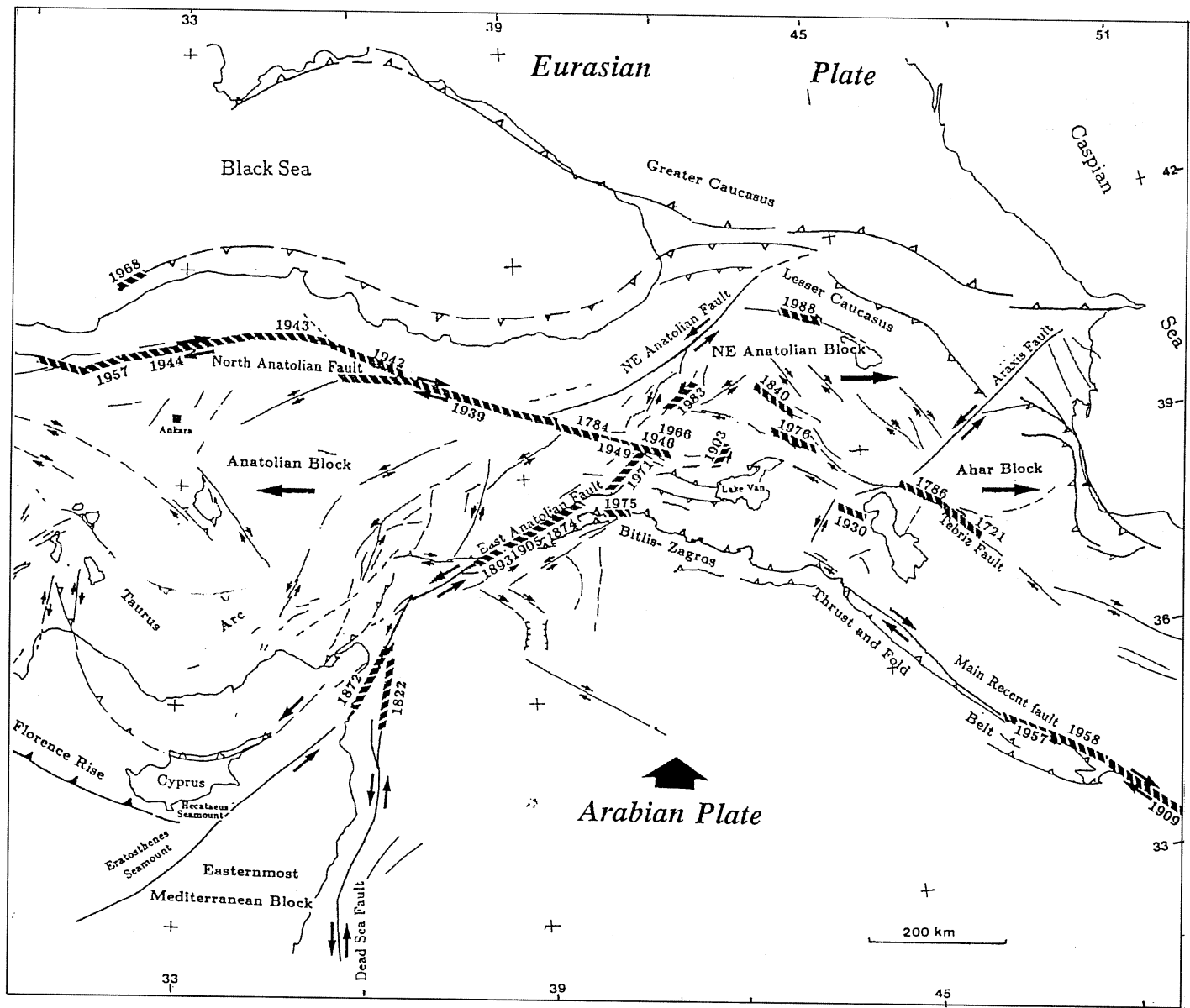

Fig. 5. Distribution and extents of surface rupture of large earthquakes in Eastern Anatolia, Caucasus and Western Iran for the last 250 years documented mostly from Ambraseys (1970, 1975, 1988, 1989), Ambraseys and Finkel (1995), Tchalenko (1977). 


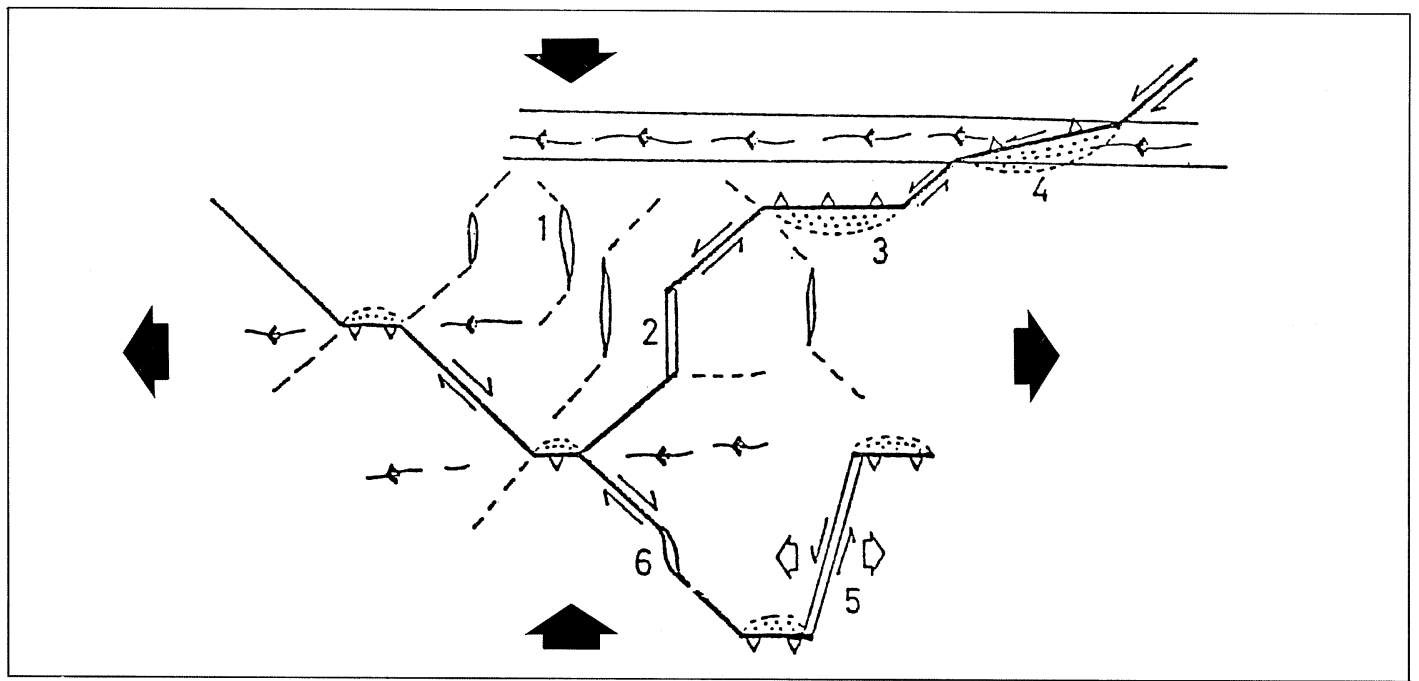

Fig. 6. Deformation pattern and types of basins resulting from the N-S shortening in Eastern Anatolia. From Şengör et al. (1985). 1 = Extension cracks; 2 and $6=$ pull-apart basins; 3 and $4=$ ramp basins; $5=$ oblique extension.

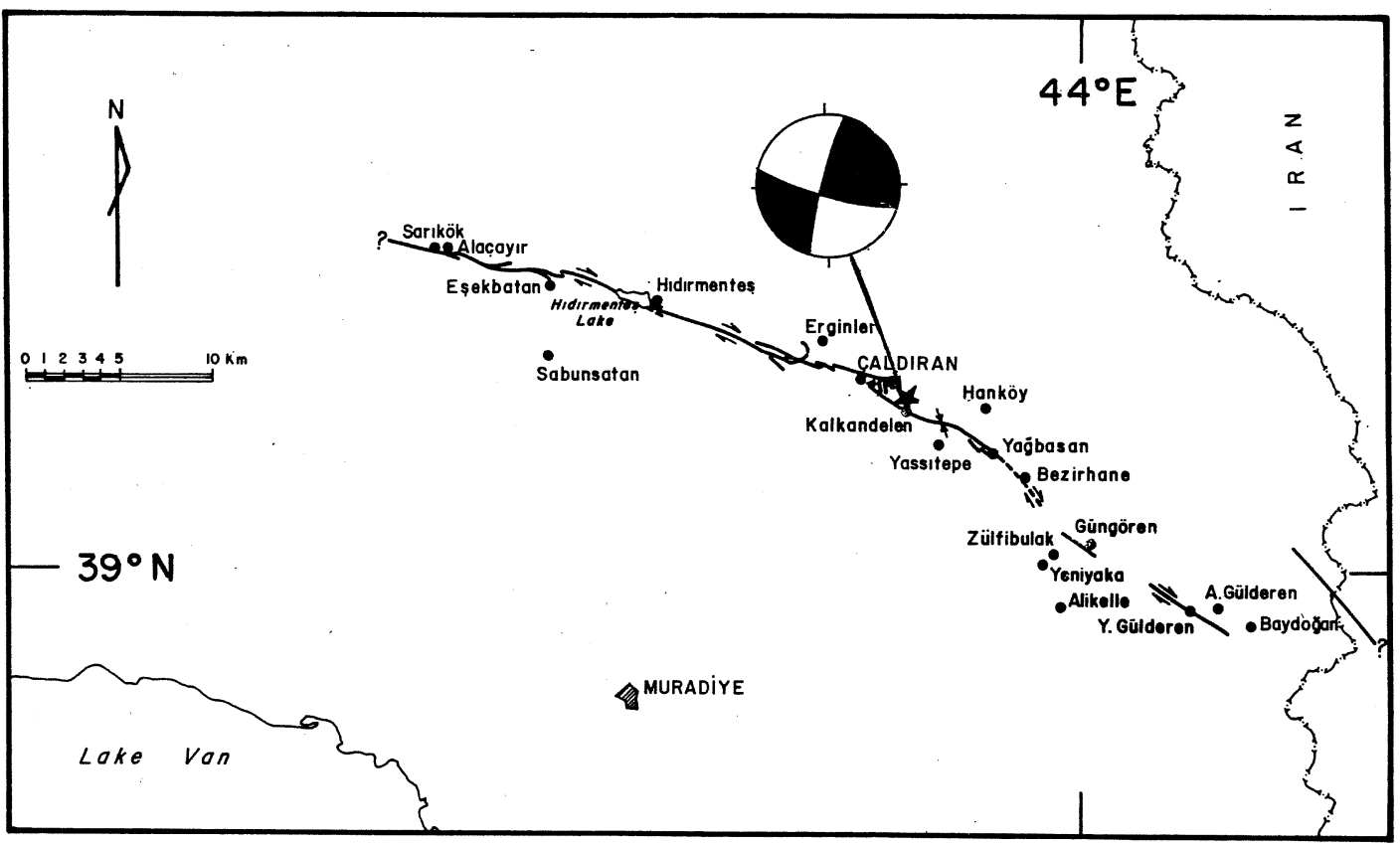

Fig. 7. Rupture zone of the 1976 Çaldıran earthquake $(M=7.1)$, Eastern Anatolia and its fault plane solution (Arpat, 1977b; Şaroğlu et al., 1983; Jackson and McKenzie, 1984). The maximum right-lateral offset was about $3.5 \mathrm{~m}$ which took place in the northeastern half of the rupture zone (Şaroğlu et al., 1983). 


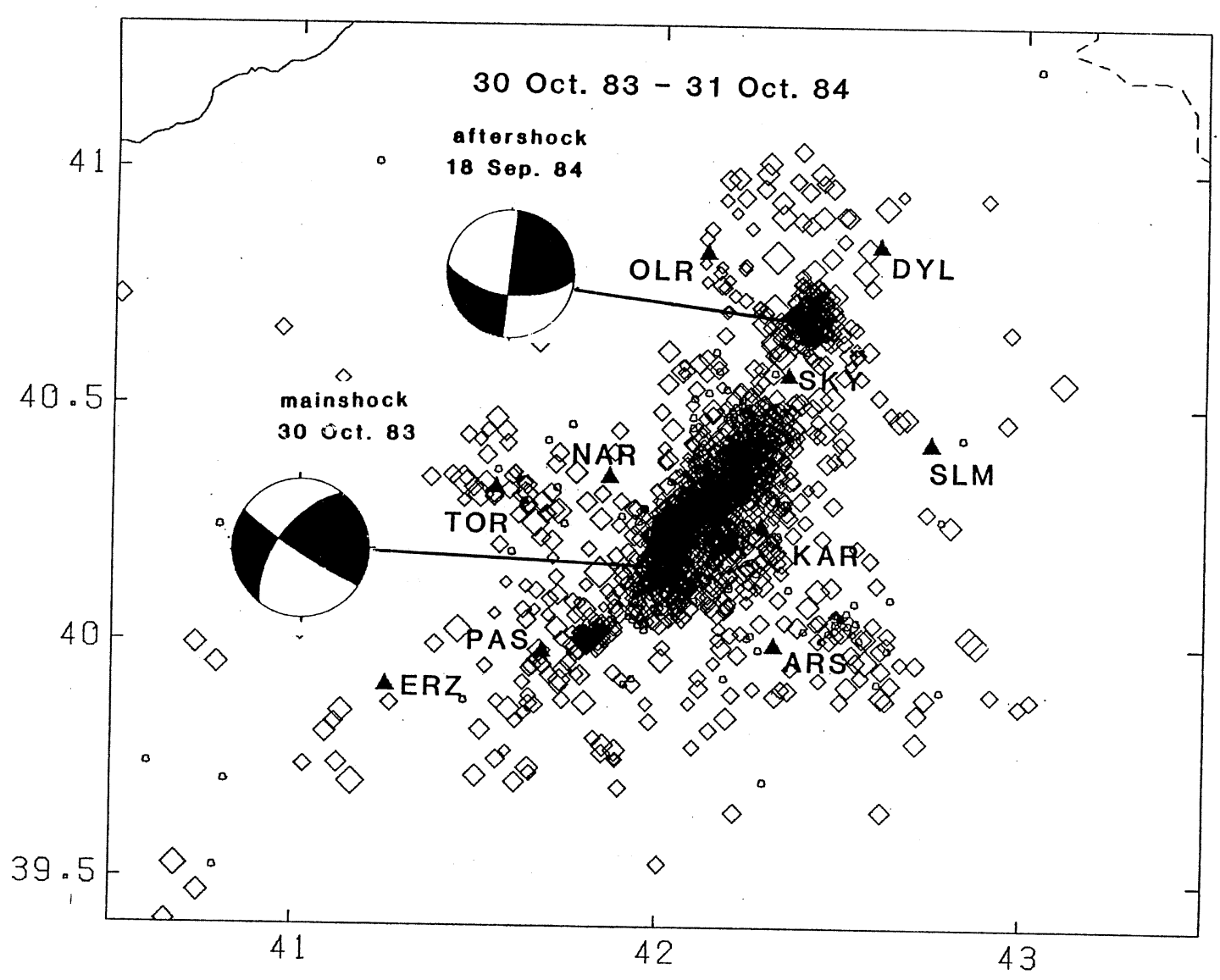

Fig. 8. Aftershock distribution and fault plane solutions of the 1983 Horasan-Narman, $M=6.8$, and 1984 Kömürlü earthquakes in Eastern Anatolia (Eyidoğan, 1990).

ments with a total length of approximately $350 \mathrm{~km}$. The fault zone steps and widens to the northeast (in places up to $10 \mathrm{~km}$ ). Tatar (1978), who first studied this fault zone, suggested that it has an oblique motion, consisting mostly of left-lateral slip with a subordinate thrust component. Earthquake records indicate that it is less active than the segments of the North Anatolian fault. GPS stations in Northeast Turkey provide some bounds on fault slip rates. All of these stations are consistent with left lateral slip. Total motion between stations AKTO and ERZU is $8 \pm 5 \mathrm{~mm} / \mathrm{yr}$ (fig. 4), (Reilinger et al., 1997). Geologic estimates of average fault slip for the segment crossing the Caucasus are given by Philip et al. (1989) as 18-25 mm/yr. However, this evidence is disputed by Triep et al. (1995) who question even the presence of a left-lateral structure crossing the Caucasus. Westaway (1994) gives an estimate of slip across this zone (termed the Erzurum Tiblisi fault zone) of $0.9 \mathrm{~mm} / \mathrm{yr}$ from summed seismic moments and of $<\sim 6 \mathrm{~mm} / \mathrm{yr}$ from kinematic considerations.

\section{Margins of the Black Sea}

The Northern margin of the Black Sea has been identified as active thrusting along the 


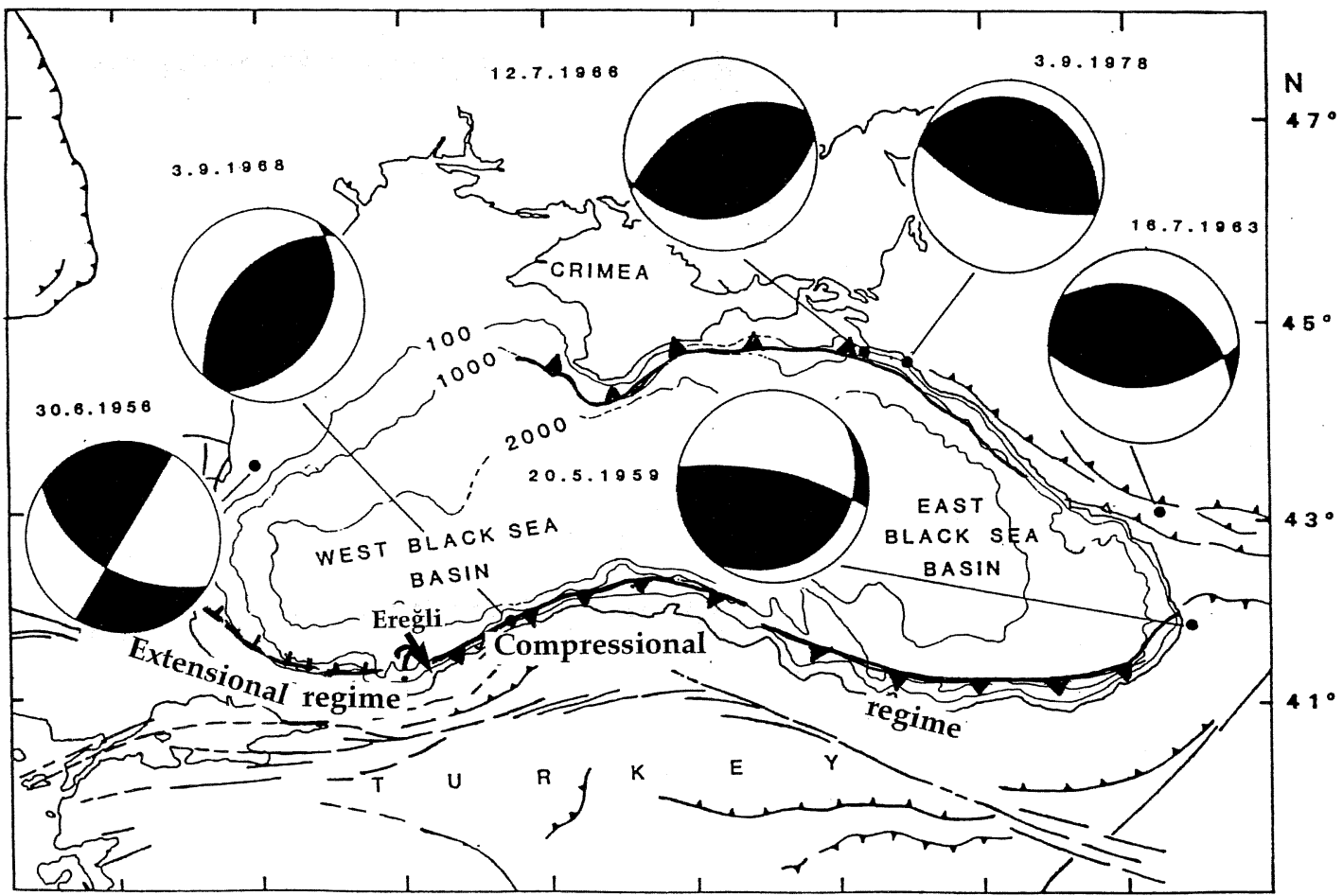

Fig. 9. Tectonics of the Black Sea (modified from Alptekin et al., 1986). Most of the southern and northern margins show shortening, except north of the Marmara Sea region (west of the $31^{\circ} \mathrm{E}$ ) and Bulgarian and Romanian coasts where it is of extensional nature (Barka, 1991).

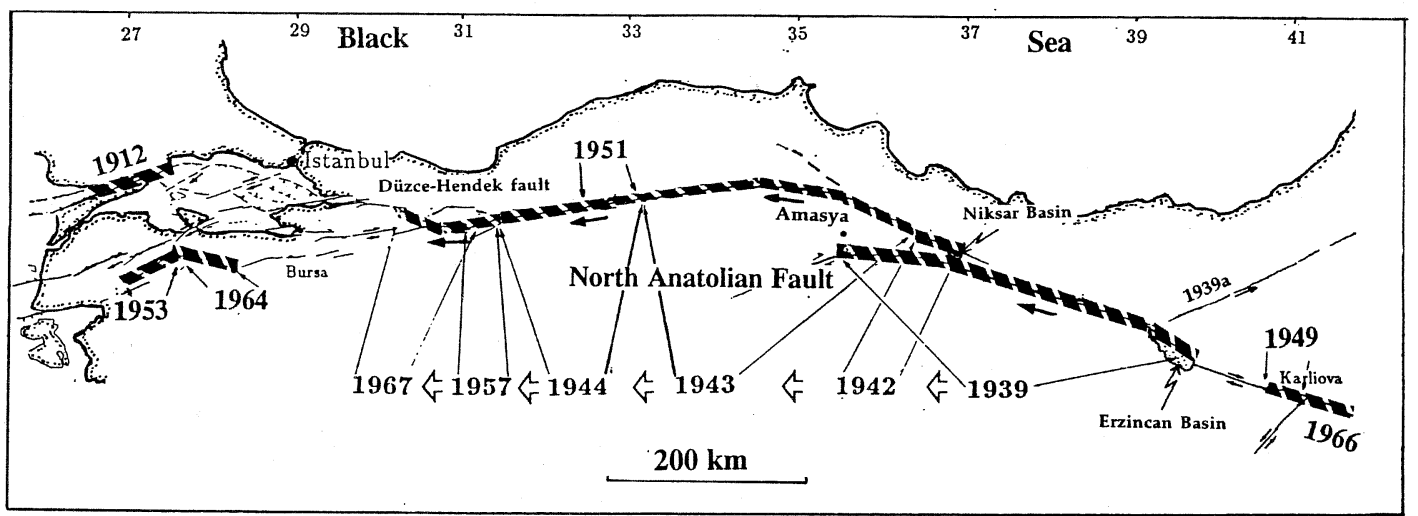

Fig. 10. Distribution of surface ruptures of consecutive large earthquakes between 1939 and 1967 and distribution of the rupture zone along the North Anatolian fault (Barka, 1992). 
Greater Caucuses from Georgia to the Crimea (fig. 9), (Jackson and McKenzie, 1984; Alptekin et al., 1986). The southern margin of the Black Sea has not been studied in detail due to the low rate of seismic activity (fig. 2). However, the 1968 Bartın earthquake $(M=6.8)$ testifies that this margin can produce destructive earthquakes (fig. 10). This margin can be divided into two subsections: the eastern section extending from the Lesser Caucasus to Ereğli, and the western section extending from Ereğli to Bulgaria. The first section shows a compressional nature, while the latter one is under extensional tectonics. Slip rates along these sections are lower than $5 \mathrm{~mm} / \mathrm{yr}$.

\section{The East Anatolian fault}

The left-lateral East Anatolian fault is the southern boundary of the westward escaping Anatolian block (figs. 1 and 6), (Şengör et al., 1985; Dewey et al., 1986; Barka and Kadinsky-Cade, 1988; Şaroğlu et al., 1992; Taymaz et al., 1992; Westaway, 1994). According to Arpat and Şaroğlu (1972) and Seymen and Aydin (1972) the fault zone has 15-27 km leftlateral post-Miocene displacement revealing about $6 \mathrm{~mm} / \mathrm{yr}$ slip rate. From seismicity and relative plate motions, Taymaz et al. (1991) estimated a $25-31 \mathrm{~mm} / \mathrm{yr}$ slip rate along the East Anatolian fault. The GPS-derived slip rate for the East Anatolian fault $(11 \pm 2 \mathrm{~mm} / \mathrm{yr})$, (Reilinger et al., 1995) is slightly higher, but statistically consistent with geological estimates, as well as with estimates based on historic earthquakes $(6-10 \mathrm{~mm} / \mathrm{yr})$. In contrast, the GPS slip rate is significantly lower than some estimates derived from plate kinematics reconstructions $(\sim 30 \mathrm{~mm} / \mathrm{yr})$. For this century, 1905 $(M=6.8), 1908(M=6.1), 1971$ Bingöl earthquake $(M=6.7)$, and 1986 Sürgü earthquake $(M=6)$ occurred on the East Anatolian fault (Ambraseys and Finkel, 1987, Taymaz et al., 1992). However, during the nineteenth century, there were large events associated with the East Anatolian fault, for example the 1866 $(M=6.8), 1874(M=7.2), 1874(M=7.1), 1893$ $(M=7.1)$, rupturing two thirds of the fault zone (Ambraseys, 1989), (fig. 6).

\section{The North Anatolian fault}

The right-lateral North Anatolian fault is the northern boundary of the anticlockwise rotating Anatolian-Aegean Block and extends over $1500 \mathrm{~km}$, from Karlıova in Eastern Turkey to the Greek mainland (e.g. Ketin, 1969; McKenzie, 1972; Şengör, 1979). The GPS data provide slip rates for the North Anatolian fault $(26 \pm 3$ $\mathrm{mm} / \mathrm{yr}$ ). The actual rate might be less than this estimate when we consider the western drift of the Pontides up to $5 \mathrm{~mm} / \mathrm{yr}$ (Oral et al., 1995). The GPS-derived slip rate for the NAF is significantly higher than long term (offset of geological features) and intermediate term (historical earthquakes) slip rates $(5-17 \mathrm{~mm} / \mathrm{yr})$, (e.g., Barka, 1992; Westaway, 1994) and significantly lower than seismic and plate closure estimates ( $-38 \mathrm{~mm} / \mathrm{yr})$, (e.g., Taymaz et al., 1991). The implications of these discrepancies are difficult to assess given the large uncertainties in the geological and seismic/closure estimates. A total of 23 large earthquakes $(M>6.5)$ occurred during the twentieth century along the entire length of the fault zone ( 7 in the North Aegean, 6 in the Marmara region and 10 along the main part). Amongst these earthquakes, six westward migrating large earthquakes $(M>7)$ occurring between 1939-1967, created a remarkable continuous $900 \mathrm{~km}$ long rupture zone (Ketin, 1948), (fig. 10), with maximum offsets of $7.5 \mathrm{~m}$ (Koçyiğit, 1989; Barka, 1992, 1996). The 1992 earthquake, $M=6.9$, which occurred in the Erzincan basin is the most recent destructive earthquake along the fault. Figure 11 shows fault plane solutions of the main shock and the largest the aftershock, and aftershock distribution (e.g., Barka and Eyidoğan, 1993). Neotectonic structures along the western side of the big bend of the North Anatolian fault indicate thrusting in Neogene sediments suggesting that the rotational motion of the Anatolian block is not perfectly tangential. This imperfect rotation might be also responsible for the thrusting along the western part of the Black Sea coast (the 1968 Bartın earthquake) and the western drift of Pontides depicted from the GPS measurements.

In the Marmara Sea region, the North Ana- 


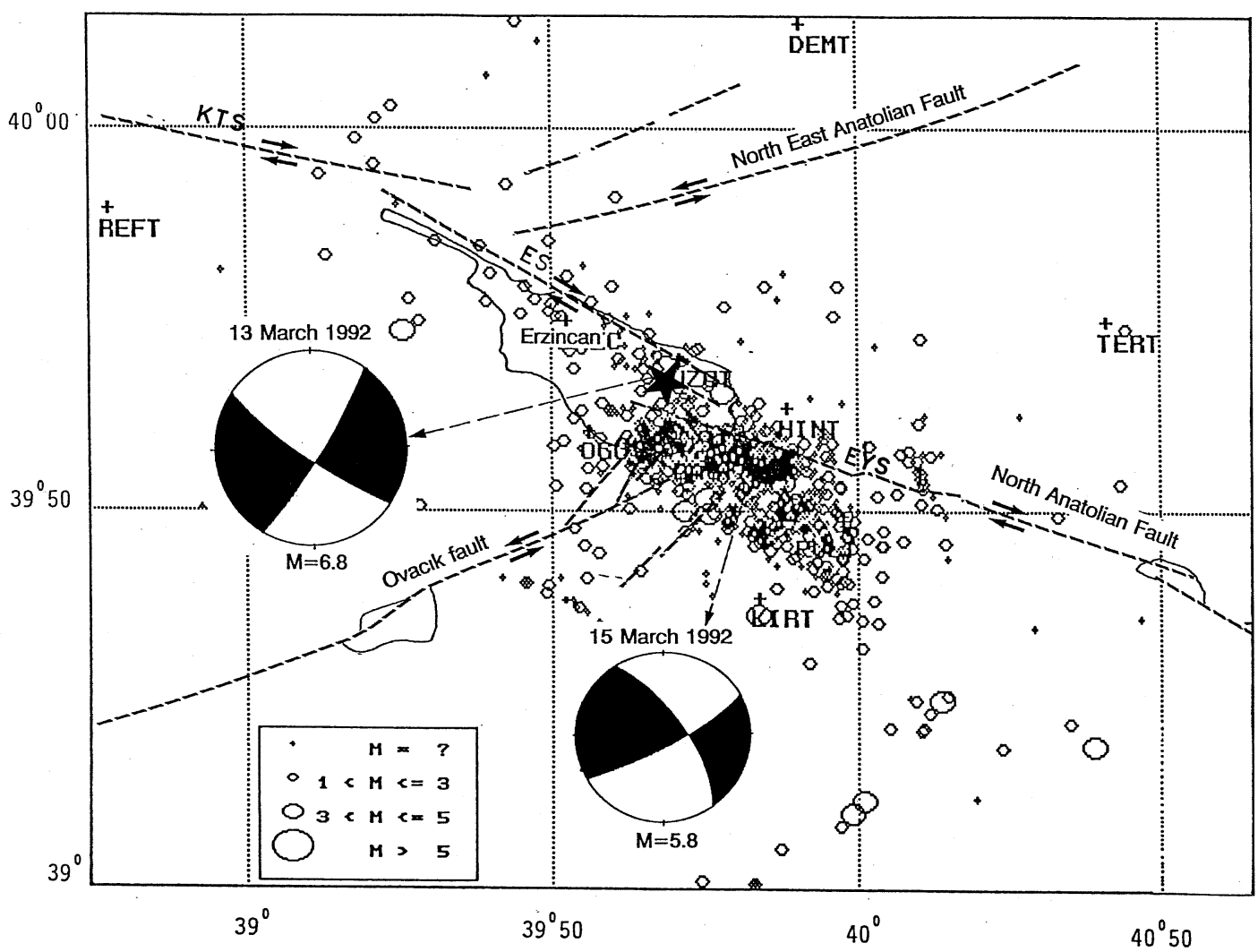

Fig. 11. Aftershock distribution (Ergintav et al., 1992) and fault mechanism of the 13 and 15 (ISC data) March 1992 earthquakes $(M=6.8, M=5.8$ respectively), from Barka and Eyidoğan (1993). The epicenter is located in the eastern half of the Erzincan basin (NEIS). EYS, ES and KTS are segments of the North Anatolian fault. REFT, DEMT, TERT, KIRT, HINT, UZAT and Erzincan are location of seismic stations. The unruptured segment of the North Anatolian fault is EYS, which last ruptured in 1784 (Ambraseys, 1975).

tolian fault zone splays into three strands and forms a diffused boundary between the Anatolian block and the Black Sea (fig. 12). Barka and Kadinsky-Cade (1988) proposed a pullapart model for the Marmara Sea region to account for the deformation and dynamics of the strands of the North Anatolian fault. This model has been generally accepted with small modifications (e.g., Wong et al., 1995; Ergün and Özel, 1995; Akgün and Ergün, 1995; Koral and Öncel, 1995). Barka (1992) further investigated the extent of the active strands of the North Anatolian fault beyond west of the Mar- mara Sea toward the North Aegean Sea and suggested that three strands cross the Marmara Sea and North Aegean region with an identical geometric pattern (figs. 12 and 13). The distribution of historical earthquakes in the last 2000 years (Ambraseys and Finkel, 1991) reveals that the northern strand has accommodated more large earthquakes than the other two southern strands. Similar results have been obtained from the GPS measurements which indicate that at least $60 \%$ of the motion is taken up by the northern strand (Straub and Kahle, 1995; Straub, 1996). 


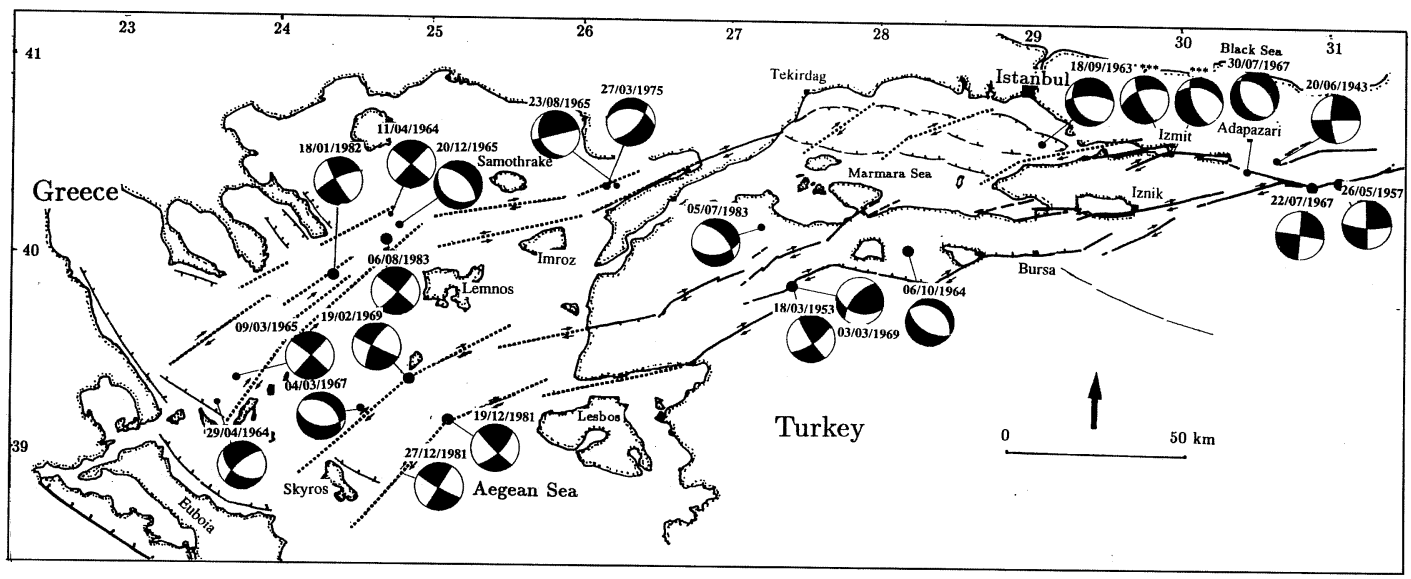

Fig. 12. Fault plane solutions of major earthquakes along the North Anatolian fault in the Marmara and North Aegean regions (compiled from McKenzie, 1972, 1978, Jackson et al., 1982; Crampin and Evans, 1986; International Seismological Center, ISC, 1981, 1982, 1983).

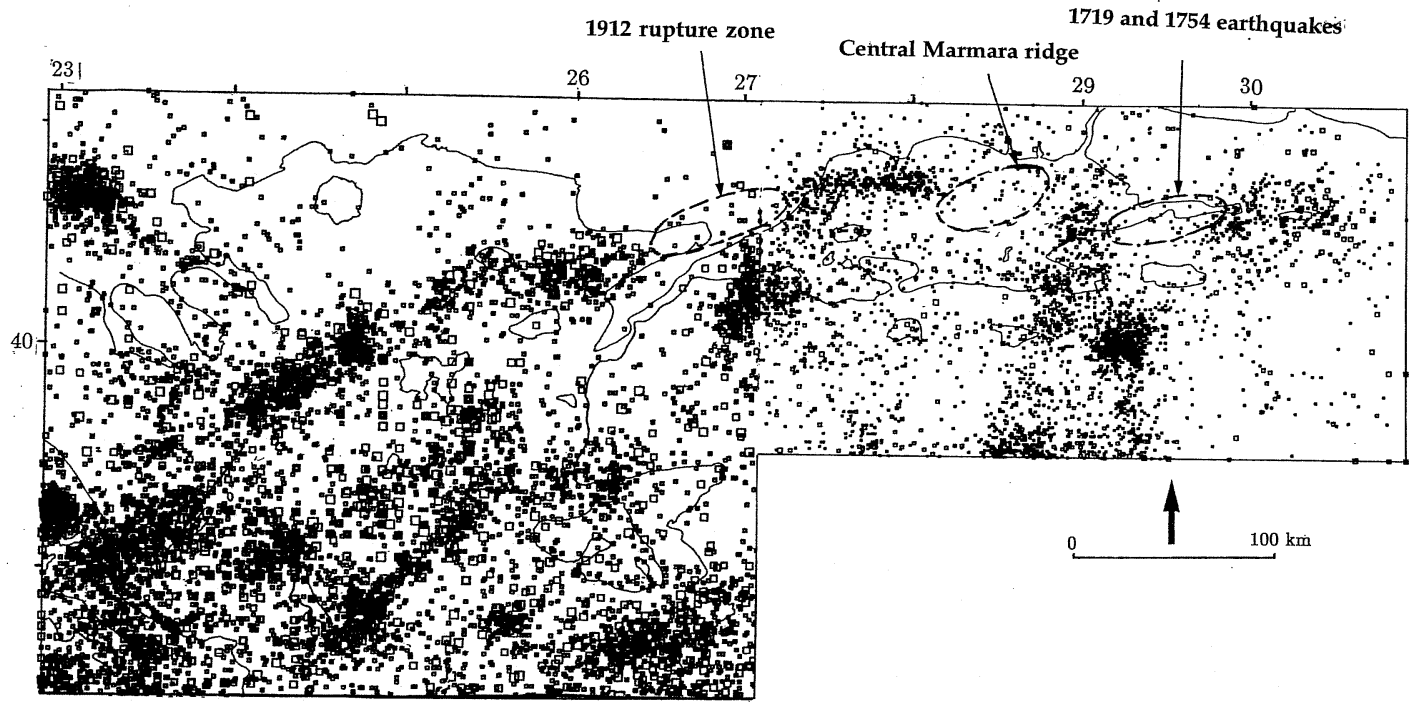

Fig. 13. Distribution of all earthquakes, $M>2.5$ in the Marmara Sea and North Aegean regions for the period 1964-1984 (ISC data, 1984). The ellipses in the Marmara Sea region indicate the locations of seismically quiet areas which coincide with major strike-slip segments. 


\section{Central Anatolia}

The Tuz gölü fault (Arpat and Şaroğlu, 1975; Aksaray-Şereflikoçhisar fault, Şengör et al., 1985) is one of the more prominent active features in Central Anatolia (figs. 1 and 4). Şaroğlu et al. (1987) suggested that in spite of some offset streams at the southern part of the fault indicating right-lateral faulting, structural observations along the fault indicate that this fault is a high angle thrust fault with a rightlateral component. The N-S and NE-SW trending volcanic cones in the vicinity of the Tuz Gölü fault are consistent with both this reverse faulting and right-lateral motion (Pasquare et al., 1988; Emre, 1991). The NNE-SSW trending Ecemiş fault (fig. 4) is a major left-lateral fault in Central Anatolia (Yetis and Demirkol, 1984). Along the fault, morphological features such as offset streams and ridges and fault line scarps are very clear. The main part of the fault zone extends from Yesilhisar to the Pozantı area, where the Ankara-Adana highway cut exhibits a considerable thrust component on the fault.

Historical (0-1900 A.D.) and instrumental earthquake records show that seismic activity in Central Anatolia has been low relative to Western Anatolia (Ambraseys, 1970, 1975, 1988; Ambraseys and Finkel, 1987), (figs. 2 and 3). The 1938 Kurssehir earthquake, $M=6.8$, is the only large earthquake that occurred during this century in this region (Parejas and Pamir, 1939; Ketin, 1969), (fig. 6). The 1717 and 1835 Ecemis earthquakes occurred near Kayseri (Öztin and Bayülke, 1990) can be listed as other important events in Central Anatolia.

The Central Taurus Mountains (Özgül, 1983) are a major neotectonic feature of SouthCentral Anatolia which is parallel to the Cyprus arc. During the early-middle Miocene time Central Anatolia was covered by a large lake whilst the Taurus Mountains were under sea level where extensive carbonate deposition occurred (Şaroğlu et al., 1983). Since the midlate Miocene the Taurus Mountains have been uplifted at least $1000 \mathrm{~m}$ relative to the Central Anatolian Plateau. The uplift has been interpreted as a wide anticlinal fold by Şaroğlu et al. (1983).
In summary, when the geometry and compressional nature of the Taurus and Pontic arcs, conjugate right-lateral Tuz Gölü and left-lateral Ecemiş faults and N-S and/or NE-SW orientations of volcanic cones are considered together, we can suggest that Central Anatolia is under approximately $\mathrm{N}-\mathrm{S}$ or NNE-SSW shortening while it is rotating anticlockwise along the North Anatolian fault. This shortening is probably related to the collisional processes along the Cyprus arc between Africa and Anatolia. Although the total amount is not clearly known, it is assumed to be approximately $10 \mathrm{~mm} / \mathrm{yr}$.

\section{The Isparta Angle}

The Isparta Angle (figs. 1 and 14), (Blumenthal, 1963) constitutes the junction between the Cyprus and Hellenic arcs and is a tectonic assemblage which has a complex tectonic history. It has been studied intensely for the last 25 years (e.g., Brunn et al., 1971; Graciansky, 1972; Monod, 1977; Poisson, 1984, 1990; Ricou et al., 1979; Gutnic et al., 1979; Sengör and Yilmaz, 1981; Yilmaz, 1983, 1984; Poisson et al., 1984; S Senel, 1983; Hayward, 1984; Robertson and Woodcock, 1984; Waldron, 1984; Marcoux, 1987; Akay and Uysal, 1988; Robertson, 1990; Kissel et al., 1993; Frizon De Lamotte et al., 1995). This zone consists of several different tectonic entities, such as the Lycian Nappes, the Antalya Nappes, the Beyşehir-Hoyran Nappes and the Alanya Massif which were emplaced between the late Cretaceous and the late Miocene (e.g., Şengör and Yilmaz, 1981). According to paleomagnetic data (Kissel et al., 1993) the angular shape of the Isparta Angle is related to the post Eocene tectonic activity. GPS measurements made in Turkey during the period of 1988-1992 indicate that the center of the Isparta Angle (Antalya site) has slower motion, less than $10 \mathrm{~mm} / \mathrm{yr}$, relative to Eurasia (Oral, 1994). By contrast, Central Anatolia (east of the Isparta Angle) moves westward relative to Eurasia at about $15 \mathrm{~mm} / \mathrm{yr}$ and Western Anatolia (west of the Isparta Angle) moves in a SW direction at $~ 30$ $\mathrm{mm} / \mathrm{yr}$ (fig. 4). Neotectonic structures in and 


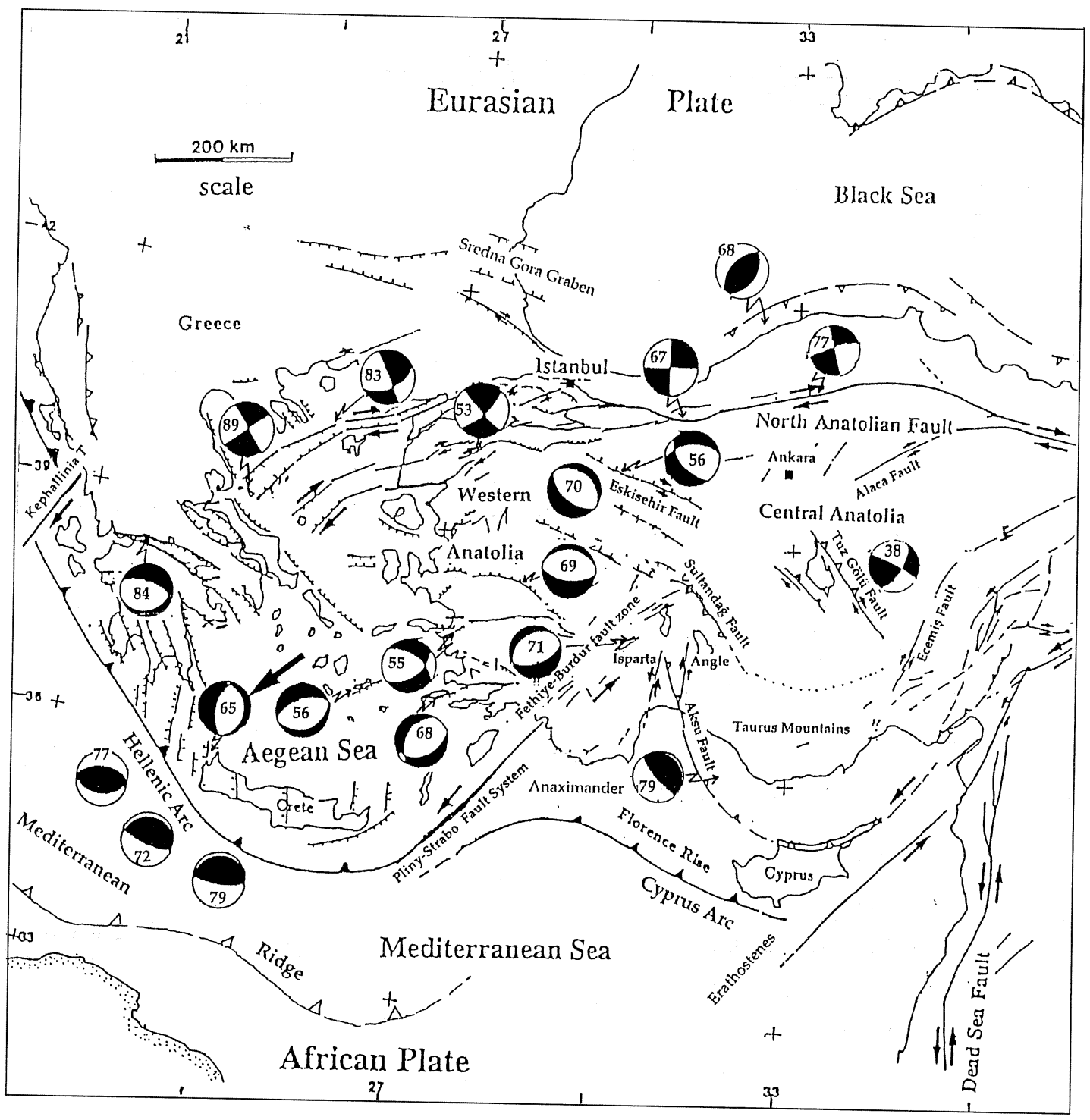

Fig. 14. Neotectonic structures in the Eastern Mediterranean region. Fault plane solutions of major earthquakes, $M>6.5$, documented from Alptekin et al. (1986), Jackson and McKenzie (1984), Taymaz et al. (1990, 1991) and Ekström and England (1989) showing that motion along the North Anatolian fault is dominantly dextral and Western Anatolia and the Aegean have dominant extension. Two digit numbers in the fault plane solutions are dates of the earthquakes. 
on the margins of the Isparta Angle, where the eastern flank is bounded by the NW-SE trending Sultandağ thrust fault (Boray et al., 1985) and the western side is made up of the transtensional left-lateral NE-SW trending Fethiye-Burdur fault zone (Dumont et al., 1979; Taymaz and Price, 1992; Price and Scott, 1994), are compatible with these GPS results (figs. 14). This tectonic nature of the Isparta Angle also suggests that the eastern flank of the Isparta Angle may slow down the westward motion of Southern Central Anatolia.

\section{Cyprus arc}

Subduction along the Cyprus arc has been a long discussed controversial subject in the literature (e.g., McKenzie, 1972; Biju-Duval et al., 1978; Büyükaşikoğlu, 1979, 1980; Harsh et al., 1981; Rotstein and Kafka, 1982; Jackson and McKenzie, 1984; Rotstein and Ben-Avraham, 1986; Kempler and Ben-Avraham, 1987; Ben-Avraham et al., 1988). Seismic data indicate subduction beneath the Florence Rise (fig. 14). The occurrence of subduction is not clear south of Cyprus (Büyükaşikoğlu, 1979, 1980; Jackson and McKenzie, 1984). In the latter area, subduction is either complicated or prevented by the sea mounts, such as the Eratosthenes (Kempler and Ben-Avraham, 1987; Ben-Avraham et al., 1988). The Anaximander sea mount is another significant structure between the Hellenic and Cyprus arcs located in the SW corner of the Isparta Angle. Offshore Isparta Angle, seismic reflection studies indicate that the Florence Rise, the Anaximander sea mount and the Antalya basin including structures in the vicinity of the Cyprus arc are all compressional features (Biju-Duval et al., 1978; Kempler and Ben-Avraham, 1987; Poisson, 1990). The subduction along the Cyprus Arc does not create an arc parallel extension on the over-riding Central Anatolia, as in the Western Anatolia/Aegean. This might suggest that the dip angle of the slab is different from the slab being subducted along the Hellenic arc (e.g., Kempler and Ben-Avraham, 1987; Wortel and Spakman, 1992), (fig. 15). This relatively lower angle of subduction is also supported by

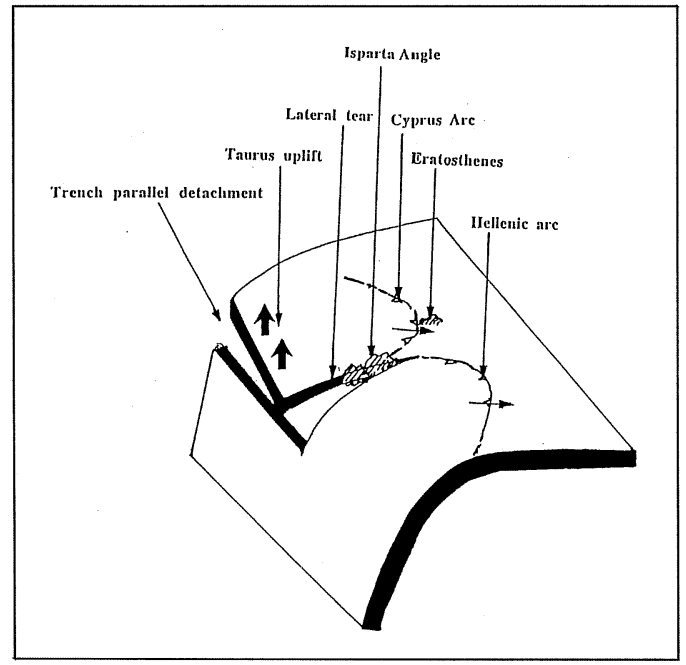

Fig. 15. Eastern Mediterranean slab geometry under the Hellenic and Cyprian arcs. The idea is partly inspired from Büyükaşikoğlu (1979), Wortel and Spakman (1992).

the location of the volcanic activity in Central Anatolia, which occurs at a considerable distance from the trench.

\section{Western Anatolia}

In Western Anatolia, E-W and WNW-ESE trending grabens and the related normal faults are the dominant neotectonic features (Philippson, 1918; Ketin, 1968; McKenzie, 1978; Dewey and Şengör, 1979; Jackson and Mc Kenzie, 1984; Şengör, 1982, 1987; Şengör et al., 1984). Among these, Gökova, Büyük Menderes, Gediz, Bakırçay and Simav grabens and the Kütahya and Eskişehir faults are the most prominent (figs. 1 and 14). A number of major normal fault events occurred along these faults, for example 1899 Büyük Menderes, 1928 Torbalı, 1955 Balat, 1969 Alaşehir, 1969 Simav, 1970 Gediz and 1995 Dinar earthquakes (e.g., Ambraseys, 1988), (fig. 16). The October 1, 1995, Dinar earthquake, $(M=6)$, occurred along the NW-SE trending Dinar fault (fig. 16). Study of the surface rupture and 


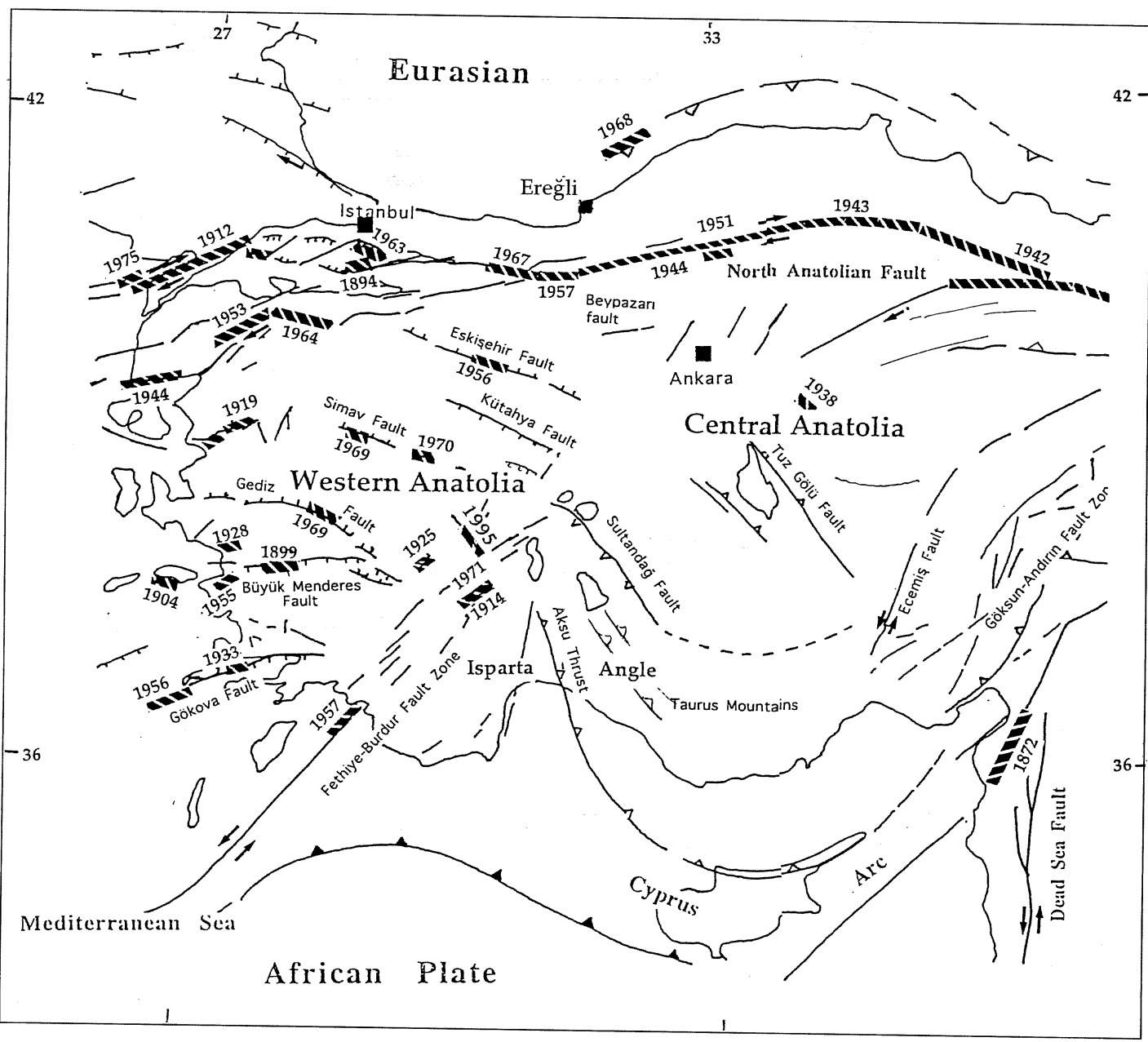

Fig. 16. Distribution of earthquake ruptures in the Anatolian region between 1800-1995. Documented from Ketin (1948), Ambraseys and Finkel (1987), Ambraseys (1988), Westaway (1990).

inversion of broad-band $P$ wave seismograms illustrated that the Dinar earthquake had dominantly normal faulting (Eyidoğan and Barka, 1996). The WNW-ESE trending Eskişehir fault, a right-lateral fault with a significant extensional component limits the extension in Western Anatolia (fig. 17). The fault extends between Uludağ and Afyon (Şaroğlu et al., 1987). The 1956 Eskişehir earthquake (Öcal, 1959), $M=6.5$, occurred along this fault and its mechanism (Jackson and McKenzie, 1984) consisted of right-lateral and extensional com- ponents being consistent with the structural nature of the fault (fig. 14). The extension in Western Anatolia steps from the northwest end of the Eskişehir fault to Bulgaria (the Sredna Gora graben, Richter, 1958) across the Marmara Sea where the strands of the North Anatolian fault cross (fig. 14). The extensional regime also influences the North Anatolian fault that splays into three strands and forms a number of pull-apart structures displaying a diffused boundary across the Marmara Sea and North Aegean (Dewey and Şengör, 1979; Şen- 


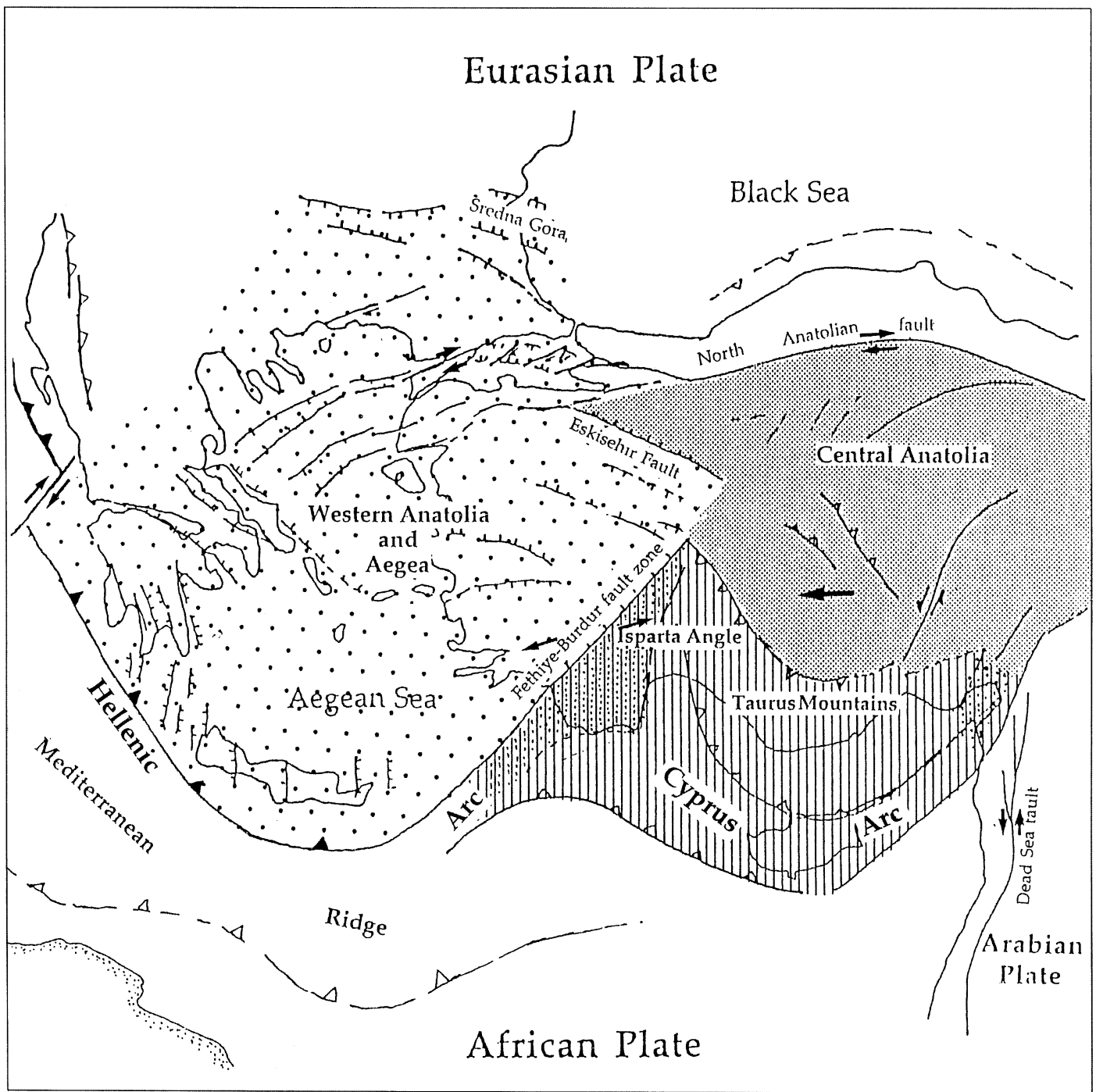

Fig. 17. Neotectonic sub-division of the Anatolian Block. Dotted zones indicate NE-SW extension, shaded area is Central Anatolia where NNE-SSW shortening currently occurs, the hatched area correspond to the complex structures of the Cyprian arc, within this, dotted parts are the extensional areas (belonging to the western flank of the Isparta Angle). Otherwise it represents compressional tectonics.

gör et al., 1985; Barka and Kadinsky-Cade, 1988; Barka, 1992). The spatial distribution extension in Western Anatolia is quite uncertain because of the relatively large uncertainties on velocity estimates and the limited sta- tion density. The available data are consistent with about $10 \pm 5 \mathrm{~mm} / \mathrm{yr}$ extension across the Bozdağ horst, Büyük Menderes and Gediz grabens and $5 \pm 5 \mathrm{~mm} / \mathrm{yr}$ extension across the Gulf of Gökova, north of the Marmaris penin- 


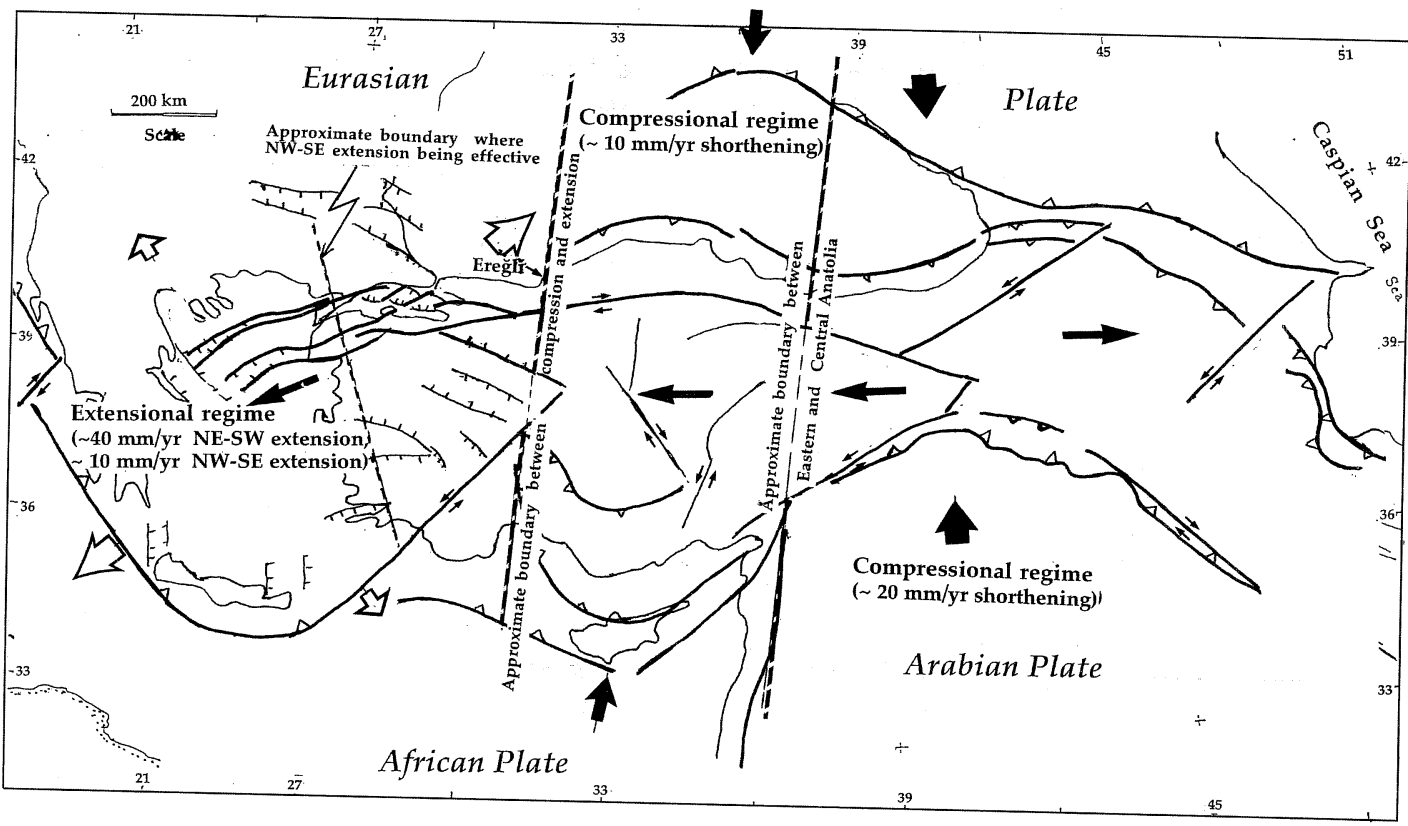

Fig. 18. Simplified tectonic map of the Eastern Mediterranean region showing the main tectonic domains and related extension and compression directions and rates obtained mostly from the GPS measurements (Reilinger et al., 1997). Solid large arrows indicate directions of shortening in Eastern and Central Anatolia, the same as northward motions of Arabia and Africa. Open arrows show directions of extension in Western Anatolia and
Aegean regions. Smaller solid arrows indicate side escapes of continental blocks.

sula. The velocities increase from $24 \mathrm{~mm} / \mathrm{yr}$ in the Southern Marmara Sea to $36 \mathrm{~mm} / \mathrm{yr}$ towards the western flank of the Hellenic arc, and to $30 \mathrm{~mm} / \mathrm{yr}$ towards the eastern flank of the Hellenic arc. The GPS vector also has a sudden 10 southerly kink along a line shown in fig. 18. The same line joins the horizontal westward opening «>» shape gulfs along the west coast of Anatolia such as Saros, Edremit, İzmir and Gökova.

\section{The Hellenic arc}

The differences in tectonic regimes in Western Anatolia/Aegean and Central Anatolia could be related to the kinematics of the subducting slabs under them. For example, it is now well established by seismic tomographic studies (e.g., Maulkamp et al., 1988; Spakman,
1991; Wortel and Spakman, 1992) that the slab being subducted along the Hellenic trench and/ or the Mediterranean Ridge Accretionary Complex seems to have a high dip angle and thus, the Hellenic trench has a retreating nature (e.g., Le Pichon and Angelier, 1979, 1981; Toksöz and Kasapoğlu, 1988; Taymaz et al., 1990; Royden, 1993). The Hellenic subduction is believed to be responsible for the extension in Western Anatolia and the Aegean since at least the middle Miocene (e.g., Seyitoğlu and Scott, 1991, 1992; Barka et al., 1994; Armijo et al., 1996). According to paleomagnetic data (Kissel and Laj, 1988; Kissel et al., 1993), the Hellenic arc was a rectilinear feature before the Langien (middle Miocene) and since then it has formed as a southward arc. Le Pichon et al. (1995) suggested that the African promontory began to collide with central part of the arc in Pliocene. 


\section{Discussion}

Even though GPS measurements have provided valuable information on the and kinematics of the plate motions, there are a few inconsistencies between velocity vectors obtained from GPS measurements and fault kinematics and rates obtained from active fault studies. These inconsistencies and some interpretations are discussed below.

a) The active fault pattern in Eastern Anatolia suggests that the Northeastern Anatolian block escapes east-northeastward. Philip et al. (1989) suggested the motion of Eastern Anatolia is northward and two strike-slip faults the left-lateral Northeast Anatolian fault and rightlateral fault along the Talesh mountains are the main boundaries for this indentation (fig. 19a). Figure 19b shows expected slip lines (fault pattern) from a wedge shape compressed Prandtl cell. This fault pattern was used by Cummings (1976) for the Mojave desert in California. A similar fault pattern exists in Eastern Anatolia which agrees with eastward escape thrusting on oceanic crust of the Southern Caspian Sea (fig. 19c). Although this is confirmed by only two GPS sites, Erzurum and Kars, the Garni site located in Armenia shows a northward motion. However, the fault plane solution of 1978 and 1980 earthquakes along the approximately N-S trending Talesh fault (Berberian, 1981; Jackson and McKenzie, 1984) indicated thrusting which is consistent with eastward motion of the Northeast Anatolian block. Thus, the Talesh mountains are more related to thrusting than right-lateral strike-slip faulting.

b) Eastern Anatolia is separated from Central Anatolia by an approximately N-S trending imaginary line as a continuity of the Dead Sea fault even though the eastern tip of the Anatolian block has a wedge geometry. To the east of this line there is at least $20 \mathrm{~mm} / \mathrm{yr}$ shortening taken up by the zone extending from the Bitlis thrust to Greater Caucasus. To the west of this line, Central Anatolia, the deformation pattern suggests that there is NNE-SSW shortening while it is rotating anticlockwise along the North Anatolian fault. This is related to the collisional nature of the Cyprus arc. Thus, the $10 \mathrm{~mm} / \mathrm{yr}$ northward motion of Africa is taken up by a wide region from the Cyprus arc to the Crimean thrust including active faults in Central Anatolia and thrusting along the southern shore of Black Sea (fig. 18).

c) Neotectonic structures and some GPS results show that the eastern flank of the Isparta Angle which is the northwestern continuation of the Cyprus arc into SW Anatolia, has less motion relative to Central Anatolia. This difference is taken up by the Sultandağ mountains and Aksu thrust (fig. 18).

d) The NE-SW extension in Western Anatolia is separated from NNE-SSW compression in Central Anatolia by a N-S line connecting the tip of the Isparta Angle and Ereğli where the Black Sea coast sharply turns to the south. However, the real separation has a wedge geometry defined by the Eskişehir and FethiyeBurdur faults (fig. 18). At the tip of the wedge, the eastward continuation of the Simav graben defines this wedge better, however, geological observations suggest that to the north of this line there are two other kinematically similar faults, the Kütahya and Eskişehir fault which should be included in Western Anatolia. This is not very clear from the GPS measurements since rates along these faults are not more than a few millimetres/year. However GPS velocities increase in Western Anatolia relative to Central Anatolia.

e) Two extension directions exist in Western Anatolia NE-SW and NW-SE caused by the western and eastern flank of the Hellenic arc respectively (fig. 18). This is due to the fact that the southern tip of the arc had already collided with Africa in the Pliocene, there are only oceanic crusts left south of the eastern and western flanks of the Hellenic arc. From the GPS vectors the western flank causes a higher rate of extension than the eastern flank. However the NW-SE extension became effective to the west of a line connecting the tips of the Gulf along the west coast of Anatolia such as Gökova, Edremit and Saros (personal discussions with S. Müller and F. Oktay, 1996). Results of this second order extension GPS vectors have at least ten sudden directional changes along this line (discussion with Le Pichon, 1995). This also results in occurrence of NW-SE, ENE-WSW and NE-SW trending nor- 
(a)
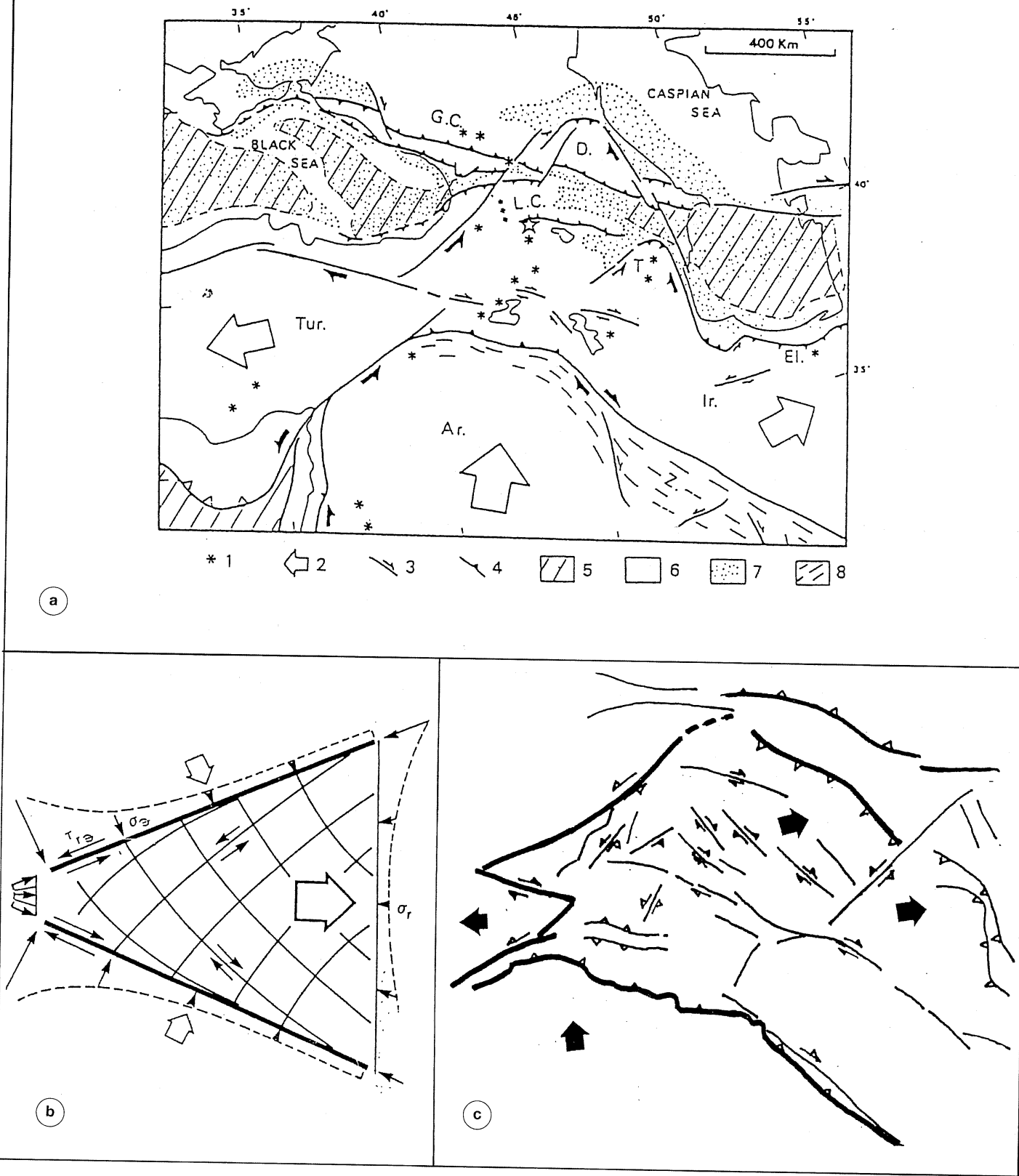

Fig. 19a-c. Neotectonic models for the Eastern Anatolia and Caucasus regions. a) From Philip et al. (1989) suggesting that the main motion of the Eastern Anatolia is NNE direction; b) Prandtl's compressed cell showing the fault patterns (Cummings, 1976); c) fault pattern in Eastern Anatolia and surrounding regions which is very similar to the fault pattern obtained from Prandtl's cell indicating that Eastern Anatolia moves westward rather than to the north. 
mal and normal-oblique faults in Western Anatolia. Consequently, smaller continental blocks sliced by these faults drift towards the southwest.

f) This interpretation illustrates that continental collision causes sideway escapes of wedge shape continental blocks (Burke and Şengör, 1986). The tectonic features of Western Anatolia show that wedge shape geometry can occur under an extensional regime where internally sliced blocks drift in certain directions.

\section{Conclusions}

The Eastern Mediterranean region offers ideal examples of continental collision (e.g., in Eastern Anatolia), oceanic subduction (e.g., along the Hellenic arc) and transition between partly collision and partly subduction (e.g., along the Cyprus arc), moderate to extensive internal deformations within the overriding continental block (e.g., Anatolia). In this region, all these processes are interacting together at present. The counter-clockwise rotation of the Anatolian-Aegean block is only a preliminary interpretation. A combined analysis of 1988-1994 GPS measurements and neotectonic observations suggest:

a) NE Anatolia moves east-northeastward.

b) The North Anatolian fault has a slip rate $26 \pm 3 \mathrm{~mm} / \mathrm{yr}$, but at least $5 \mathrm{~mm} / \mathrm{yr}$ should be extracted for the western drift of Pontides.

c) The present neotectonic regime in Western Anatolia and the Aegean Sea differs from that in Central Anatolia. In Western Anatolia and the Aegean, approximately E-W and WNW-ESE trending graben and normal faults are dominant structures and this region is extending in a SW-NE direction at a rate of roughly 30-40 mm/yr (Oral et al., 1995; Le Pichon et al., 1995). In contrast, neotectonic structures in Central Anatolia consist of strikeslip and thrusting, indicating that Central Anatolia is undergoing a NNE-SSW shortening (see also Şengör et al., 1985) and is moving in a more westerly direction at a rate of about $15-20 \mathrm{~mm} / \mathrm{yr}$ (Oral et al., 1995). Furthermore, internal deformation in Central Anatolia ap- pears to be significantly less than in Western Anatolia as testified by seismic activity (e.g., Ambraseys, 1970, 1975). This suggests that Central Anatolia is more rigid even though it accommodates a number of large active faults. Western Anatolia is separated from Central Anatolia by the WNW-ESE trending Eskișehir fault and the NE-SW trending Fethiye-Burdur fault zone (fig. 14). GPS measurements indicate that the interior of the Isparta Angle zone is a relatively stable domain, located between Central and Western Anatolia. However, each of its flanks has been affected by deformation due to the motion of the neighboring tectonic blocks with respect to Eurasia.

d) The segmentation of the subduction in the Eastern Mediterranean into the Hellenic and the Cyprus arcs is believed to be responsible for compartmentalization of tectonic regimes on the overriding Anatolia (i.e., the extension in Western Anatolia and Aegean region and compression in Central Anatolia).

It is hoped that continuing GPS efforts will clarify problems related to the kinematics and dynamics of the Eastern Mediterranean region as the amount of sites and accuracy GPS measurements increase.

\section{Acknowledgements}

I would like thank two anonymous referees who's comments greatly improved the paper. This research was supported in part by NSF Grant EAR-9304554 to MIT and TYDABÇAG-237-G. National Marine Geology and Geophysics Program (coordinator Naci Görür) and Glotek unit both supported by TÜBİTAK.

\section{REFERENCES}

AKAY, E. and Ş. UYSAL (1988): Orta Torosların postEosen tektoniği, MTA Dergisi, 108, 57-68.

AKGÜN, M. and M. ERGÜN (1995): Izmit Körfezinin yapısı ve Kuzey Anadolu fayı (KAF) ile ilişkisinin irdelenmesi, Jeofizik, 9 (1-2), 71-78.

AlPTEKIN, Ö., J.L. NABELEK and N.M. ToKsÖZ (1986): Source mechanism of the Bartin earthquake of September 3, 1968 in Northwestern Turkey: Evidence for ac- 
tive thrust faulting at the Southern Black Sea margin, Tectonophysics, 122, 73-88.

AMBRASEYS, N.N. (1970): Some characteristic features of the North Anatolian fault zone, Tectonophysics, 9 , 143-165.

Ambraseys, N.N. (1975): Studies in historical seismicity and tectonics, in Geodynamics of Today, The Royal Soc. London, 7-16.

AmBRASEYS, N.N. (1988): Engineering seismology, Earthquake Eng. Struct. Dyn., 17, 1-105.

AMBRASEYS, N.N. (1989): Temporary seismic quiescence: SE Turkey, Geophys. J., 96, 411-331.

Ambraseys, N.N. and C.F. FinKel (1987): Seismicity of the Northeast Mediterranean region during early 20th Century, Annales Geophysicae, 5B, 701-726.

Ambraseys, N.N. and C.F. FINKEL (1991): Long term seismicity of Istanbul and the Marmara Sea region, Terra Nova, 3, 527-539.

Ambraseys, N.N. and C.F. FinKel (1995): The Seimicity of Turkey and Adjacent Areas, Publ. Eren, pp. 240.

ARMiJo, R., H. LYON-CAEN and D. PAPANASTASSIOU (1992): East-west extension and Holocene normal-fault scarps in the Hellenic arc, Geology, 20, 491-494.

Armijo, R., B. Meyer, G.C.P. King, A. Rigo and D. PAPANASTASSIOU (1996): Quaternary evolution of the Corinth and its implications for the late Cenozoic evolution of the Aegean, Geophys. Res. Int., 126, 11-53.

ARPAT, E. (1977a): 1975 Lice Depremi, Yer Yuvarl ve Ínsan, 2, 18-28.

ARPAT, E. (1977b): 1976 Çaldıran Depremi, Yer Yuvarl ve Insan, 2, 29-42.

ARPAT, E. and F. ŞAROĞLU (1972): The East Anatolia Fault System: thoughts on its development, Bull. Miner. Res. Explor. Inst. Turkey, 78, 33-39.

ARPAT, E. and F. ŞAROGLU (1975): Some recent tectonic events in Turkey, Türkiye Jeoloji Kurumu Bült., 18, 91-101.

BARKA, A.A. (1991): İstanbulu'un Depremselliğini oluşturan tektonik yaplar ve İstanbul için bir mikro-bölgelendirme denemesi, «Istanbul ve Deprem Sempozyumu» Inşaat Müh, Odası, 35-56.

BARKA, A.A. (1992): The North Anatolian fault, Anneles Tectonicae, 6, 164-195.

BARKA, A.A. (1996): Slip distribution along the North Anatolian fault associated with the large earthquakes of the period 1939-1967, Bull. Seism. Soc. Am., 86, 12381254.

BARKA, A.A. and H. EYIDOĞN, (1993): The March 13, 1992 Erzincan earthquake, Terra Nova, 5 (2), 190-194.

BARKA, A.A. and K. KADINSKY-CADE (1988): Strike-slip fault geometry in Turkey and its influence on earthquake activity, Tectonics, 7 (3), 663-684.

BARKA, A.A., F. ŞAROĞLU and Y. GÜNER (1983): 1983 Horasan-Narman earthquake and its place in the neotectonics of Eastern Turkey, Yer Yuvart ve Insan, 8, 16-21.

BARKA, A.A., M. SAKINÇ, N. GÖRÜr, Y. YILMAZ, A.M.C. ŞENGÖR and V. EDIGER (1994): Is Aegean extension a consequence of the westerly escape of Turkey?, EOS, Trans. Am. Geophys. Un., 75, 116-117.

Ben-Avraham, Z., D. Kempler and A. GinzBurg (1988): Plate convergence in the Cyprus Arc, Tectonophysics, 146, 231-240.
BERBERIAN, M. (1981): Active faulting and tectonics of İran, in Zagros, Himalaya: Geodynamic evolution, in Geodynamic Series, edited by H.K. GuPTA and F.M. Delany, Amer. Geophys. Un., 3, 33-69.

Buu-Duval, B., J. Letouzey and L. Montadert (1978): Structure and evolution of the Mediterranean basins, Initial Reports of DSDP, 42, 951-984.

Blumenthal, M.M. (1963): Le systeme structural du Taurus sud Anatolien, Paul Fellot, 2, Soc. Geol. France, 611-662.

BORAY, A., F. ŞAROĞLU and Ö EMRE (1985): Isparta bülümünün kuzey kesiminde D-B daralma için bazı veriler, Jeoloji Müh., 23, 9-20.

Brunn, J.H., J.F. Dumont, P.C. De Graciansky, M. Gutnic, T. Juteau, J. Marcoux and A. Poisson (1971): Outline of the geology of the Western Taurides, in Geology and History of Turkey, edited by A.S. CAMPWELL, Petroleum Exploration Society of Libya, Tripoli, 225-257.

BurKE, K. and A.M.C. ŞENGÖR (1986): Tectonic escape in the evolution of the continental crust, in Reflection Seismology, Continental Crust, Geodynamic Series, edited by M. BARAZAngI, Amer. Geophys. Un., 14, 41-51.

BÜYÜKAŞıKOĞLU, S. (1979): Seismolojik Verilere Göre Guney Anadolu ve Doğu Akdeniz'de Avrasya-Afrika Levha Sınırının Özellikleri, İstanbul Technical University, Istanbul, pp. 75.

BÜYÜKAŞIKOĞLU, S. (1980): Eurasian-African plate boundary in Southern Turkey and Eastern Mediterranean, in Proceedings of the 7th World Conference on Earthquake Engineering, Geoscience Aspects, part 1, 209-212.

Crampin, S. and R. Evans (1986): Neotectonics of the Marmara Sea region of Turkey, J. Geol. Soc. London, 143, 343-346.

Cummings, D. (1976): Theory of plasticity applied to faulting, Mojave Desert, Southern California, Geol. Soc. Amer. Bull., 87, 720-724.

DeMets, C., R.G. Gordon, D.F. Argus and S. Stein (1990): Current plate motions, Geophys. J. Int., 1001, 425-478.

DeMets, C., R.G. Gordon, D.F. Argus and S. Stein (1994): Effects of recent revisions to the geomagnetic reversal time scale on estimates of current plate motions, Geophys. Res. Lett., 21, 2191-2194.

Dewey, J. F. and A.M.C. ŞENGör (1979): Aegean and surrounding regions: complex multiplate and continuum tectonics in a convergent zone, Geol. Soc. Am. Bull., 90, 84-92.

Dewey, J.F., M.R. HEMPTON, W.S.F. KIDD, F. ŞAROLĞU, and A.M.C. ŞENGÖR, (1986): Shortening of Continental lithosphere: the tectonics of Eastern Anatolia - young collision zone, in Collision Tectonics, edited by M.P. CowArd and A.C. Ries, Geol. Soc. London, Spec. Publ., 19, 3-36.

Dumont, J.F., A. Poisson and A. ŞAHinci (1979): Sur l'existence de coulissements sénestres récents a l'extrémité orientale de l'arc égéen (sud-ouest de la Turquie), C. R. Acad. Sc. Paris, t. 289, 261-264.

EkströM, G. and P. ENGLAND (1989): Seismic strain rates in regions of distributed continental deformation, $J$. Geophys. Res., 94, 10231-10257. 
EMRE, Ö. (1991): Hasandağ-Keçiborlu Dağı yöresi volkanizmasının jeomorfolojisi, Ph.D. Thesis, Istanbul University, pp. 207.

Ergintav, S., F. BiçMEN, A. YörüK, H. Kaplan, M. AKTAR and N. YALÇIN (1992): 13 Mart 1992 Erzincan depremi sonrası deprem etkinliği, Erzincan Depremi ve Türkiye Deprem Sorunu, İtü, Maden Fakültesi Yayını, 52-55.

ERGÜN, M. and E. ÖZEL (1995): Structural relationship between the sea of Marmara basin and the North Anatolian fault, Terra Nova, 7, 278-288.

EYIDOGAN, H. (1980): The source parameters of the Lice, Turkey earthquake, in Individual Studies by Participants at the IISEE, Tokyo, 16, 107-130.

EyỉdoGAN, H. (1990): The Narman, Eastern Turkey earthquake of 30 October 1983: Active conjugate faulting and the migration of the seismicity, in Proceedings Workshop on Historical Seismicity and Seismitectonics of the Mediterranean Region, Turkish Atomic Energy Authority Ankara, Turkey, 224-233

EyIDOĞAN, H. and A.A. BARKA (1996): The October 1, 1995, Dinar earthquake, SW Turkey, Terra Nova, 8, 479-485.

Frizon De Lamotte, D., A. Poisson, C. Aubourg and H. TEMIZ (1995): Post-Tortonian westward and southward thrusting in the core of the Isparta re-entrant (Taurus, Turkey). Geodynamic implications, Bull. Soc. Geol. France, 166, 59-67.

Freund, R., Z. GARFunKel, I. ZAK, M. GoldberG, T. WeIsSBRoD and B. BERIN (1970): The shear along the Dead Sea rift, Phil. Trans. R. Soc. London, Ser. A, 267, 107-130.

FuenZAlidA, H. (1995): Etude de source de seismes complexes par inversion des ondes de volume (large-bande) dans la region du Caucase, $P h D$. Thesis, University Louis Pasteur de Strasbourg, France, pp. 202.

FuenzalidA, H., L. Rivera, H. HAESSlER, D. LEGRAND, H. Philip, L. Dorbath, D. McCormack, S. ArefieV, C. LANGerand and A. Cisternas (1997a): Seismic source study of the Racha-Dzhava (Georgia) earthquake from aftershocks and broad-band teleseismic body wave records: an example of active nappe tectonics, Geophys. Int. J. (in press).

Fuenzalida, H., L. Dorbath, A. Cisternas, L. Rivera, H. EyidoĞan, A.A. Barka, H. HAessler, H. Philip and N. LYBERIS (1997b): Mechanism of the 1992 Erzincan earthquake and its aftershocks, tectonics of the Erzincan basin and decoupling on the North Anatolian fault, Geophys. Int. J., 129, 1-28.

GRACIANSKY, P.C. (1972): Reserches géologiques dans le Taurus Lycien occidental, Thèse Doctorat d'Etat, Université de Paris-Sud Orsay, No. 896, pp. 762.

Gutnic, M., O. Monod, A. Polsson and J.F. Dumont (1979): Géologie des Taurides occidentals (Turquie), Mem. Soc. Géol. Fr. Paris, N.S. 137, pp. 112.

Haessler, H., A. Deschamps, H. Dumumier, H. FuenZALIDA and A. CISTERNAS (1992): The rupture process of the Armenian earthquake from broad-band teleseismic body wave records, Geophys. J. Int., 109, 151-161.

Harsch, W., T. Kupfer, B. Rust and R. SAgesser (1981): Seismotectonic consideration on the nature of the Turkish-African plate boundary, Geol. Rundsch., 70, 368-384.
HAYWARD, A.B. (1984): Miocene clastic sedimentation related to the emplacement of the Lycian nappes and the Antalya complex, SW Turkey, in The Geological Evolution of the Eastern Mediterranean, edited by J.E. DiXon and A.H.F. RoberTson, Geol. Soc. London, Spec. Publ., 17, 287-300.

JACKSON, J. (1994): Active tectonics of the Aegean region, Ann. Rev. Earth Planet. Sci., 22, 239-271.

JACKSON, J.A. and D. MCKENZIE (1984): Active tectonics of the Alpine-Himalayan belt between Western Turkey and Pakistan, Geophys. J. R. Astron. Soc., 77, 185-264.

JACKSON, J., G. KING and C. VITA-FINZI (1982): The tectonics of the Aegean: an alternative view, Earth Planet. Sci. Lett., 61, 303-318.

Kempler, D. and Z. Ben-Avraham (1987): The tectonic evolution of the Cyprean arc, Annales Tectonicae, 1, 58-71.

KeTiN, İ. (1948): Über die tektonisch-mechanischen Folgerungen aus den grossen anatolischen Erdbeben des letzten Dezenniums, Geol. Rudsch., 36, 77-83.

KETIN, İ. (1968): Relations between general tectonic features and the main earthquake regions of Turkey, MTA Bulletin, 71, 63-67.

KETIN, İ. (1969): Über die nordanatolische Horizontalverschiebung, Bull. Mineral Res. Explor. Inst. Turkey, 72 , $1-28$.

KISSEL, C. and C. LAJ (1988): Tertiary geodynamical evolution of the Aegean arc: a paleomagnetic reconstruction, Tectonophysics, 146, 183-201.

Kissel, C., O. Averbuch, D. Frizon De Lamotte, O. MONOD and S. AlLERTON (1993): First paleomagnetic evidence for a post-Eocene clockwise rotation of Western Taurides thrust belt east of the Isparta re-entrant (Southwestern Turkey), Earth Planet. Sci. Lett., 117, 1-14.

KoçYiGiT, A. (1989): Suşehri basin; an active fault wedge basin, Tectonophysics, 167, 13-29.

KORAL, H. and A.O. ÖNCEL (1995): Izmit körfezinin yapısal ve sismolojik özellikleri, Jeofizik, 9 (1-2) 79-82.

Le Pichon, X and J. Angelier (1979): The Hellenic arc and trench system: a key to the neotectonic evolution of the Eastern Mediterranean area, Tectonophysics, 60, $1-42$.

Le Pichon, X. and J. Angelier (1981): The Aegean sea, Philos. Trans. R. Soc. London, Ser. A, 300, 357-372.

Le Pichon, X., N. Chamot-Rooke, S. Lallemant, R. NoOMEN and G. VeIS (1995): Geodetic determination of the kinematics of Central Greece with respect to Europe: implications for Eastern Mediterranean tectonics, J. Geophys. Res., 100, 12675-12690.

Marcoux, J. (1987): Histoire et topologie de la NeoTethys, These de Doctorat D'Etat, Université Pierre et Marie Curie, Paris, pp. 569.

Maulkamp, J.E., M.J.R. Wortel, W.A.V. Spakman and N.J. VlaAR (1988): The Hellenic subduction zone: a tomographic image and its geodynamic implications, Geophys. Res. Lett., 15, 60-63.

MCKenZIE, D.P. (1972): Active tectonics of the Mediterranean region, Geophys. J. R. Astron. Soc., 30 (2), $109-185$.

McKenZIE, D.P. (1978): Active tectonics of the AlpineHimalayan belt: the Aegean Sea and surrounding re- 
gions (tectonics of Aegean region), Geophys. J. R. Astron. Soc., 55, 217-254.

MonOD, O. (1977): Recherches Géologiques dans de la Taurus occidental au sud de Beyşehir (Turquie), These, Univ. Paris Sud Orsay, pp. 442.

ÖCAL, N. (1959): 1956 Eskişehir depremi makro ve mikrosismik gözlemleri, İtü, Sismoloji Enstitüsü Yayını, pp. 48.

ORAL, B.M. (1994): Global Positioning System (GPS) measurements in Turkey (1988-1992): Kinematics of Africa-Arabia-Eurasia collision zone, PhD. Thesis, Massachussetts Institute of Technology, pp. 344.

Oral, B., R. ReIlenger, N.M. ToksÖZ, R. King, A. BARKA, I. KINIK and O. LENK (1995): Coherent plate motion in the Eastern Mediterranean continental collision zone, EOS, January, 1-3.

ÖZGÜL, N. (1983): Stratigraphy and tectonic evolution of the Central Taurides, in Geology of the Taurus Belt, edited by O. Tekeli and C. GöncüoĞlu, Spec. Pub. MTA, Ankara, 77-90.

ÖZTiN, F. and N. BAYÜLKE (1990): Historical earthquakes of İstanbul, Kayseri and Elazı̆̆, in Proceedings Workshop on Historical Seismicity and Seismitectonics of the Mediterranean region, Turkish Atomic Energy Authority Ankara, Turkey, 234-253.

PAREJAS, E. and H.N. PAMIR (1939): 19/4/1938 orta Anadolu yer depremi, İst. Üni. Fe. Fak. Meo. b IV, $3 / 4$.

Pasquare, G., S. Poli, L. Venzolli and A. Zanchi (1988): Continental arc volcanism and tectonic setting in Central Anatolia, Tectonophysics, 146, 217-230.

Philip, H., A. Cisternas, A. Gvishiani and A. GorSHKOV (1989): The Caucasus: an actual example of the initial stages of continental collision, Tectonophysics, 161, 1-21.

PhilipPSON, A. (1918): 1910-1915 Reisen und Forschungen im Westlichen Kleinasien, Ergänzungshefte 167, 172, 177, 180, 183 der Petermanns Mitteilungen, Gotha, Justus Perthes.

PoIsson, A. (1984): The extension of the Ionian trough into SW Turkey, in The Geologic Evolution of the Eastern Mediterranean, edited by J.F. DIXON and A.H. Robertson, Geol. Soc. London, Spec. Publ., 17, 241-249.

Poisson, A. (1990): Neogene thrust Belt in Western Taurides. The Imbricate Systems of Thrust Sheets Along a NNW-SSE Transect, IESCA-1990, 224-235.

PoIsson, A., E. AKAY, J.F. DUMONT and S. UYSAL (1984): Isparta Angle (W. Taurids): a Mesozoic paleorift, in Geology of the Taurus Belt, edited by $\mathrm{O}$. Tekeli and C. GöncüoĞlu, Spec. Publ. MTA, Ankara, 11-26.

PRICE, S. and B. SCOTT (1994): Fault-block rotations at the edge of a zone of continental extension; Southwest Turkey, J. Struct. Geol., 16, 381-392.

RICHTER, C.F. (1958): Elementary Seismology, edited by J. GrithHely and A.O. WoOdFord (W.H. Freeman and Company, San Francisco), pp. 550.

Ricou, L., J. Marcoux and A. Poisson (1979): L'allochtonie des Bey Dağları orientaux. Reconstruction palinpastique des Taurides occidentales, Bull. Soc. Geol. France, 21, 125-133.

Reilinger, R., N. TOKSÖZ, R. KING, S. MCClusky,
B. Oral, I. Kinik, O. Lenk, I. SAnli, A.A. Barka, M. Prilepin, A. Mishin, S. Balassanian, G. Veis, D. Paradissis, A. Tealeb, Y. Melzer, J. NormanDEAU and D. MENCIN (1995): 1994 GPS Measurements in Turkey and Surrounding Areas of the E. Mediterranean / Middle East, abstract, IUGG, Boulder, U.S.A

Reilinger, R., S. McCluskys, B. Oral, R. King, N. TOKSÖZ, A. BARKA, I. KINIK, O. LENK and I. SANLI (1997): Global Positioning System measurements of present-day crustal movements in the Arabia-AfricaEurasia plate collision zone, J. Geophys. Res. (in press).

Robbins, J.W., P.J. Dunn, M.H. Torrence and D.E. SMITH (1995): Deformation in the Eastern Mediterranean, in Proceedings of the First International Symposium on Deformations, Chamber of Surveying Enginners, Ankara, Turkey, 2, 738-745.

RoBERTSON, A.H.F. (1990): Microplate Tectonics and Evolution of the Mesozoic-Tertiary Antalya Complex, IESCA-1990, 243-252.

RoberTson, A.H.F. and N.H. WookCock (1984): The SW segment of the Antalya Complex, Turkey as a Mesozoic-Tertiary Tethyan, continental margin, in The Geologic Evolution of the Eastern Mediterranean, edited by J.F. Dixon and A.H. Robertson, Geol. Soc. London Spec. Publ., 17, 251-271.

RotsteIn, Y. and A.L. KAFKA (1982): Seismotectonics of the southern boundary of Anatolia, Eastern Mediterranean region, subduction, collision and arc jumping, J. Geophys. Res., 87, 7694-7706.

Rotstein, Y. and Z. Ben-Avraham (1986): Active tectonics in the Eastern Mediterranean: role of oceanic plateous and accreted Terranes, Israel J. Earth Sci., 35, 23-39.

RoYden, L. (1993): Evolution of retreating subduction boundaries formed during continental collision, Tectonics, 12, 303-325.

ŞAROĞLU, F. and Y. GüNER (1981): Doğu Anadolunun jeomorfolojik gelisimine etki eden öğeler; jeomorfoloji, tektonik and volkanizma ilişkileri, Türkiye Jeol. Kur. Bült., 24, 269-282.

ŞaroĞlu, F., E. Boray, S. ÖZER and İ. KuşçU (1983): Orta Toroslar-Orat Aandolu'nun güneyinin neotektoniği ile ilgili görüşler, Jeomorfoloji Dergisi, 11, 35-44.

ŞAROĞLU, F., A. BORAY and O. EMre (1987): Active faults of Turkey, Mineral Res. Explor. Inst. Turkey, Unpubl. Report, 8643, pp. 394.

ŞAROĞLU, F., O. EMre and I. Kuscu (1992): The East Anatolian fault zone of Turkey, Annales Tectonicae, 6 , 99- 125

ŞENEL, M. (1983): Discussion on the Antalya nappes, in Geology of the Taurus belt, edited by O. TEKELI and C. GöncüOĞLU, Spec. Publ. MTA, Ankara, 41-52.

ŞENGÖR, A.M.C. (1979): The North Anatolian transform fault: its age, offset and tectonic significance, J. Geol. Soc., 136, 269-282.

ŞENGÖR, A.M.C. (1982): Ege'nin neotektonik evrimini yöneten etkenler, in Batı Anadolu'nun Genç Tektoniğ i ve Volkanizmast Paneli, edited by O. EROL and V. ÖYGÜR, Türkiye Jeoloji Kurumu, Ankara, 59-72.

ŞENGÖR, A.M.C. (1987): Cross-faults and differential 
streching of hanging walls in regions of low angle normal faulting: example from Western Turkey, in Continental Extensional Tectonics, edited by M.P. COWARD, J.F. Dewey and P.L. Hancock, Geol. Soc. London, Spec. Publ., 28, 575-589.

ŞENGÖR, A.M.C. and Y. YILMAZ (1981): Tethyan evolution of Turkey: a plate tectonic approach, Tectonophysics, 75, 181-241.

ŞENGÖR, A.M.C., M. SATIR and R. AKKöK (1984): Timing of tectonic events in the Menderes massif, Western Turkey: Implications for tectonic evolution and evidence for Pan-African basement in Turkey, Tectonics, 3, 693-707.

ŞENGÖR, A.M.C., N. Görür and F. ŞAROĞLU (1985): Strike-slip faulting and related basin formation in zones of tectonic escape: Turkey as a case study, in Strikeslip Faulting and Basin Formation, edited by K.T. BIDDKe and N. Christie-Blick, Society of Econ. Paleont. Min. Spec. Publ., 227-264.

SeyitoĞlu, G. and B.C. Scott (1991): Late Cenozoic crustal extension and basin formation in West Turkey, Geol. Mag., 128, 155-166.

SeyitoGluU, G. and B.C. SCOTT (1992): The age of the Büyük Menderes graben (West Turkey) and its tectonic implications, Geol. Mag., 129, 239-242.

SEymen, I. and A. Aydin, (1972): The Bingöl earthquake fault and its relation to the North Anatolian fault zone, Bull. Mineral Res. Explor. Inst. Turkey, 79, 1-8.

SPAKMAN, W. (1991): Delay-time tomography of the upper mantle below Europe, the Mediterranean, and Asia Minor, Geophys. J. Int., 107, 309-332.

Stiros, S. (1995): Unexpected shock rocks an aseismic area, EOS, December 5, 1.

Straub, C. (1996): Recent crustal deformation and strain accumulation in the Marmara Sea region, NW Anatolia inferred from GPS measurements, PhD. Thesis, ETH, pp. 122 .

Straub, C. and H.G. KAHLE (1995): Active crustal deformation in the Marmara Sea region, NW Anatolia, inferred from GPS measurements, Geophys. Res. Lett., 22, 2533-2536.

TATAR, Y. (1978): Tectonic investigations on the North Anatolian fault zone between Erzincan and Refahiye, Publ. Inst. Earth. Sci. Hacettepe Univ., 4, 201-136.

TAyMaZ, T. and S.P. Price (1992): The 12.05.1971 Burdur earthquake sequence: a synthesis of seismological and geological observations, Geophys. J. Int., 108, 589-603.

TAYMAZ, T., J. JACKSON and R. WESTAWAY (1990): Earth- quake mechanisms in the Hellenic Trench near Crete, Geophys. J. Int., 102, 695-631.

TAYMAZ, T., J. JACKSON and D.P. MCKEnZIE (1991): Active tectonics of the North and Central Aegean Sea, Geophys. J. Int., 106, 433-490.

TAYMAZ, T., H. EyIDOĞAN and J. JACKSON (1992): Source parameters of large earthquakes in the East Anatolian fault zone (Turkey), Geophys. J. Int., 106, 537-550.

TCHALENKO, J.S. (1977): A reconnaissance of the seismicity and tectonics at the northern border of the Arabian Plate (Lake Van region), Geogr. Phys. Geol. Dyn., 19, 189-208.

TOKSÖZ, M.N. and E. KASAPOĞLU (1988): Collision of the Arabian and Eurasian plates: finite element models, EOS Abstract, T51A-2.

Triep, E.G., G.A. Abers, A.L. Lerner-Lam, V. MishatKİN, N. ZAKHARCHENKO and O. STAROVOIT (1995): Active thrust front of the Greater Caucasus: the April 29, 1991 Racha Earthquake Sequence and its tectonic implications, J. Geophys. Res., 100, 4011-4034.

WALDRON, J.W.F. (1984): Structural history of the Antalya Complex in the «Isparta Angle», Southwest Turkey, in The Geologic Evolution of the Eastern Mediterranean, edited by J.F. Dixon and A.H. RoberTson, Geol. Soc. London, Spec. Publ., 17, 273-286.

WestawAy, R. (1990): Continental extension on sets of parallel faults: observational evidence and theoretical models, in The Geometry of Normal Faults, edited by A.M. Roberts, G. Yielding and B. Freeman, Geol. Soc. London, Spec. Publ., 56, 143-169.

Westaway, R. (1994): Present-day kinematics of the Middle East and Eastern Mediterranean, J. Geophys. Res., 99, 12071-12090.

WONG, H.K., T. LÜDMAN, A. UluĞ and N. GÖRÜR (1995): The sea of Marmara: a plate boundary sea in an escape tectonic regime, Tectonophysics, 244, 231-250.

WORTEL, M.J.R. and W. SPAKMAN (1992): Structure and dynamics of subducted lithosphere in the Mediterranean region, Proc. K. Ned. Akad. Wet., 95, 325-347.

Yetiş, C., and C. Demirkol (1984): Geotectonic evolution of the Ecemiş fault zone, Yerbilimleri, 11, 1-12.

YilmaZ, P.O. (1983): The Alakır çay unit, Anatalya complex: a tectonic enigma, in Geology of the Taurus Belt, edited by O. TeKeli and C. GöncüoĞLu, Spec. Publ. MTA, Ankara, 27-40.

YILMAZ, P.O. (1984): Fossil and k-ar data for the age of the Antalya complex, SW Turkey, in The Geologic Evolution of the Eastern Mediterranean, edited by J.F. Dixon and A.H. RoberTSOn, Geol. Soc. London, Spec. Publ., 17, 97-109. 